*ak RMIS View/Frint Document Cover Sheet tow

This document was retrieved from the Documentation and Records Manaqement (DRM) ISEARCH System. It is intended for Information only and may not be the most recent or updated version. Contact a Document Service Center (see Hanford Info for locations) if you need additional retrieval information.

Accession \#: D196027053

Document \#: SD-WM-ETP-176

Title/Desc:

LDUA SYS HOT TEST

Pages: 69 


\section{FEB 141996 212 ENGINERRING DATA TRANSMITTAL}

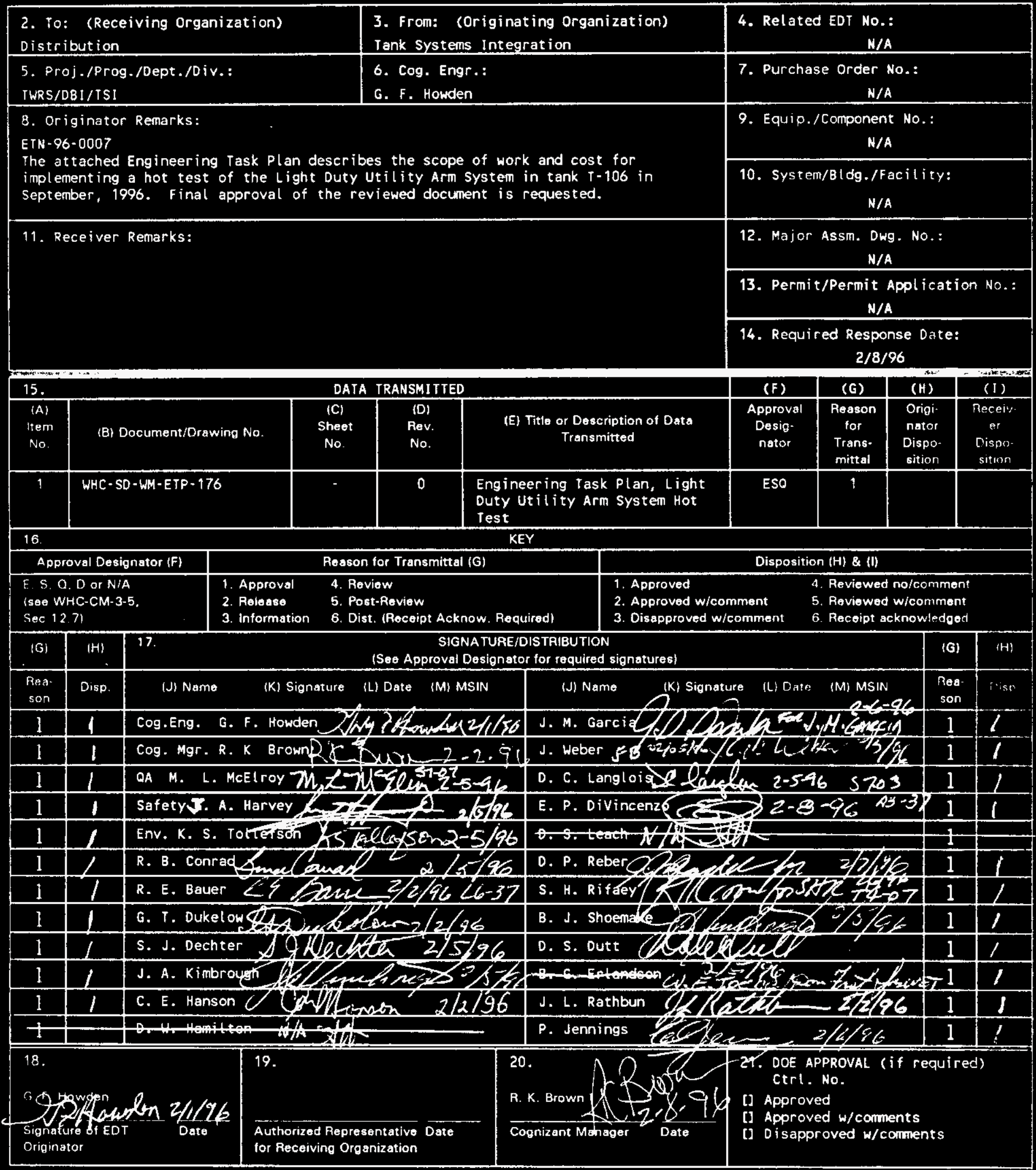

BD-7400-172-2(04/94) GEF097 


\title{
Light Duty Utility Arm System Hot Test
}

\author{
G. F. Howden \\ R. B. Conrad \\ G. R. Kiebel \\ Westinghouse Hanford Company, Richland, WA 99352 \\ U.S. Department of Energy Contract DE-AC06-87RL10930
}
EDT/ECN: EDT 612364 UC: EM-2020
Org Code: 74420 Charge Code: N2206
B\&R Code: EW3120072 Total Pages: 66

Key Words: ETN-96-0007, LDUA, T-106, Hot Test, Task P1an

Abstract: This Engineering Task Plan describes the scope of work and cost for implementing a hot test of the Light Duty Utility Arm System in Tank T-106 in September 1996.

TRADEMARK DISCLAIMER. Reference herein to any specific commercial product, process, or service by trade nane, tradenark, manufacturer, or otherwise, does not necessarily constitute or imply its endorsenent, recommendation, or favoring by the United States Government or any agency thereof or its contractors or subcontractors.

Printed in the United States of America. To obtain copies of this document, contact: WHC/BCS Document Control Services, P.O. Box 1970, Mailstop H6-08, Richland WA 99352, Phone (509) 372-2420; Fax (509) 376-4989.
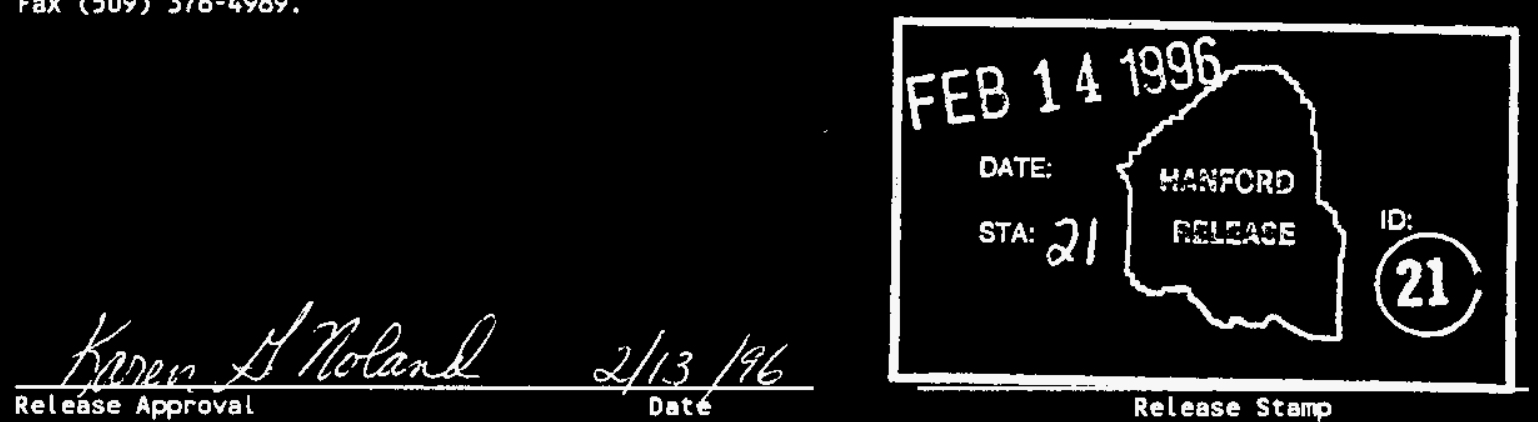

\section{Approved for Public Release}


WHC-SD-WM-ETP-176 Rev. 0

Engineering Task Plan

\section{LIGHT DUTY UTILITY ARM SYSTEM HOT TEST}

G. F. Howden

R. B. Conrad

G. R. Kiebel

February 1, 1996

ETN-96-0007 
WHC-SD-WM-ETP-176 Rev. 0

\section{CONTENTS}

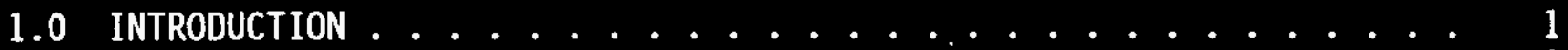

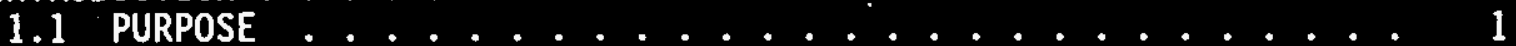

1.2 BACKGROUND . . . . . . . . . . . . 1

1.3 SYSTEM DEVELOPMENT TURNOVER FOR BENEFICIAL OPERATION . . . . . 1

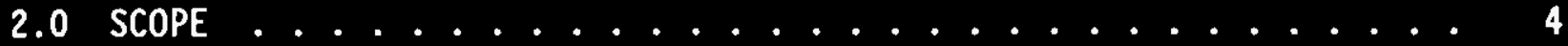

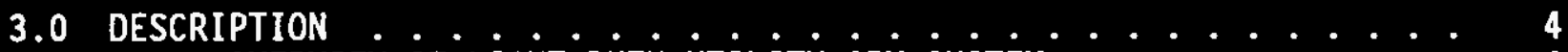

3.1 OVERVIEW OF LIGHT DUTY UTILITY ARM SYSTEM ........ 4

3.1.1 LDUA System Setup ............. 6

3.1.2 System Operation .............. 9

3.1.3 System Hierarchy Description......... 9

3.2 ARM/DEPLOYMENT SYSTEM ............. 10

3.2.1 Mobile Deployment System (MDS) . . . . . . . . 10

3.2.2 Vertical Positioning Mast \& Housing (VPM) ..... 11

3.2.3 Light Duty Utility Arm (LDUA) .......... 11

3.2.4 Tool Interface Plate (TIP) . .......... 11

3.2.5 Arm/Deployment System Local Control . . . . . 13

3.3 LDUA TO TANK RISER INTERFACE EQUIPMENT ........... 13

3.3.1 Isolation Valve and Spool Piece ........ 13

3.3.2 Decontamination Module and Radiation Monitor . . . . 13

3.3.3 Tank Riser Interface Confinement (TRIC) Module . . . . 14

3.3.4 Manual End Effector Exchange System ......... 14

3.4 LDUA SYSTEM BASIC TOOL KIT . . . . . . . . . . 15

3.4.1 Overview Stereo Video System . . . . . . . . . 15

3.4.2 Overview Video System ........... 15

3.4.3 High Resolution Stereo Video System End Effector . . . 15

3.4.4 Gripper End Effector .............. 15

3.4.5 In Situ Moisture Detector End Effector........ 15

3.4.6 Surface Sampler End Effector ........... 15

3.4.7 Topographical Mapping System . . . . . . . . 15

3.4.8 Riser Characterization Equipment ........ 16

3.4 .9 Opt ical Al ignment Scope ........... 16

3.5 OPERATIONAL SUPPORT EQUIPMENT ............ 16

3.5.1 Power Distribution Skid ............ 16

3.5.2 At Tank Instrument Enclosure .......... 16

3.5.3 Operations Control Trailer ........... 17

3.5.4 Decon Water Supply System ........... 18

3.5.5 Engine/Generator ............. 18

3.5.6 Tank Exhauster . . . . . . . . . . 18

3.6 AUDIO AND VISUAL COMMUNICATIONS EQUIPMENT . . . . . . . 18

3.6.1 Field Audio Communications . . . . . . . . 18

3.6.2 Visual Communications .......... 19

4.0 ORGANIZATIONS AND MANPOWER ESTIMATES ............ 19

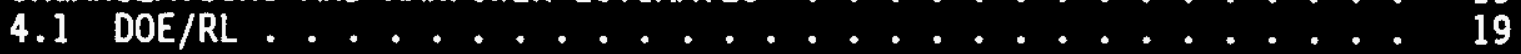

4.2 CHARACTERIZATION PROJECT .................. 19

4.2.1 Characterization Operations ......... 19

4.2.2 Characterization Equipment Engineering ...... 21 
CONTENTS (cont.)

4.3 TANK FARMS TRANSITION PROJECTS ............ 22

4.3.1 West Tank Farm Transition Project ......... 22

4.3.2 Environmental Cleanup/Compliance Project ...... 23

4.3.3 Training \& Procedures ............ 23

4.4 TWRS ENGINEERING ............... 23

4.4.1 SAFETY ENGINEERING ............... 23

4.4.2 TWRS Design Basis Integration ......... 24

4.5 EMERGENCY/SAFETY QUALITY SERVICES .......... 25

4.5.1 Characterization Project ESQ . . . . . . . . 25

4.5.2 Tank Waste Remediation System Quality Assurance ... 25

4.6 SAFETY . . . . . . . . . .... 26

4.6.1 TWRS Safety Integration ......... 26

4.7 SAFETY ANALYSIS AND NUCLEAR ENGINEERING ........ 26

4.7.1 TWRS SAR Engineering ............. 26

4.7.2 Consequence Analysis ............. 26

4.8 PROJECT SERVICES ................ 28

4.8.1 Environmental Services . . . . . . . . . 28

4.9 ENGINEERING TESTING AND TECHNOLOGY PROJECTS . . . . . . 29

4.9.1 Remote Systems/Sensor Applications ......... 29

4.10 OTHER SUPPORTING ORGANIZATIONS ............ 29

4.11 ASSUMPTIONS AND CONDITIONS ............ 31

4.11.1 Assumptions ............... 31

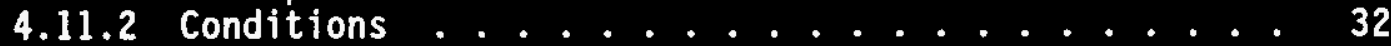

4.11.3 Hot Testing Support and Equipment Maintenance ... 32

4.11.4 Turnover ............... 32

5.0 SCHEDULE MILESTONES ................ 33

6.0 COST ESTIMATE SUMMARY . . . . . . . . . . . . 34

6.1 EXPENSE COST ESTIMATE SUMMARY . . . . . . . . 34

6.2 CENRTC FUNDED EQUIPMENT AND MATERIALS COST ESTIMATE SUMMARY • 36

7.0 QUALITY ASSURANCE ................ 36

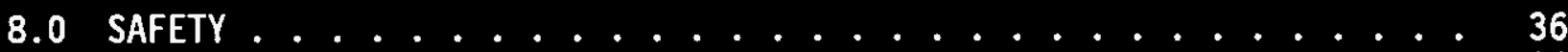

8.1 FIRE SAFETY CRITERIA ............... 36

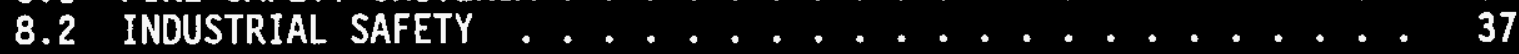

9.0 SYSTEMS ENGINEERING . . . . . . . . . . . 37

10.0 REFERENCES ......................... 37

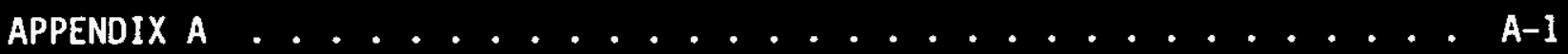

APPENDIX B ............................ B-1

APPENDIX $\mathrm{c} \ldots \ldots \ldots \ldots \ldots \ldots$

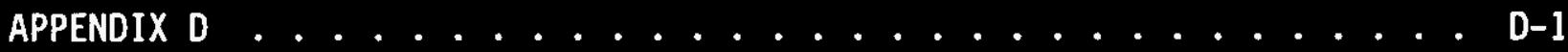




\section{ACRONYM LIST}

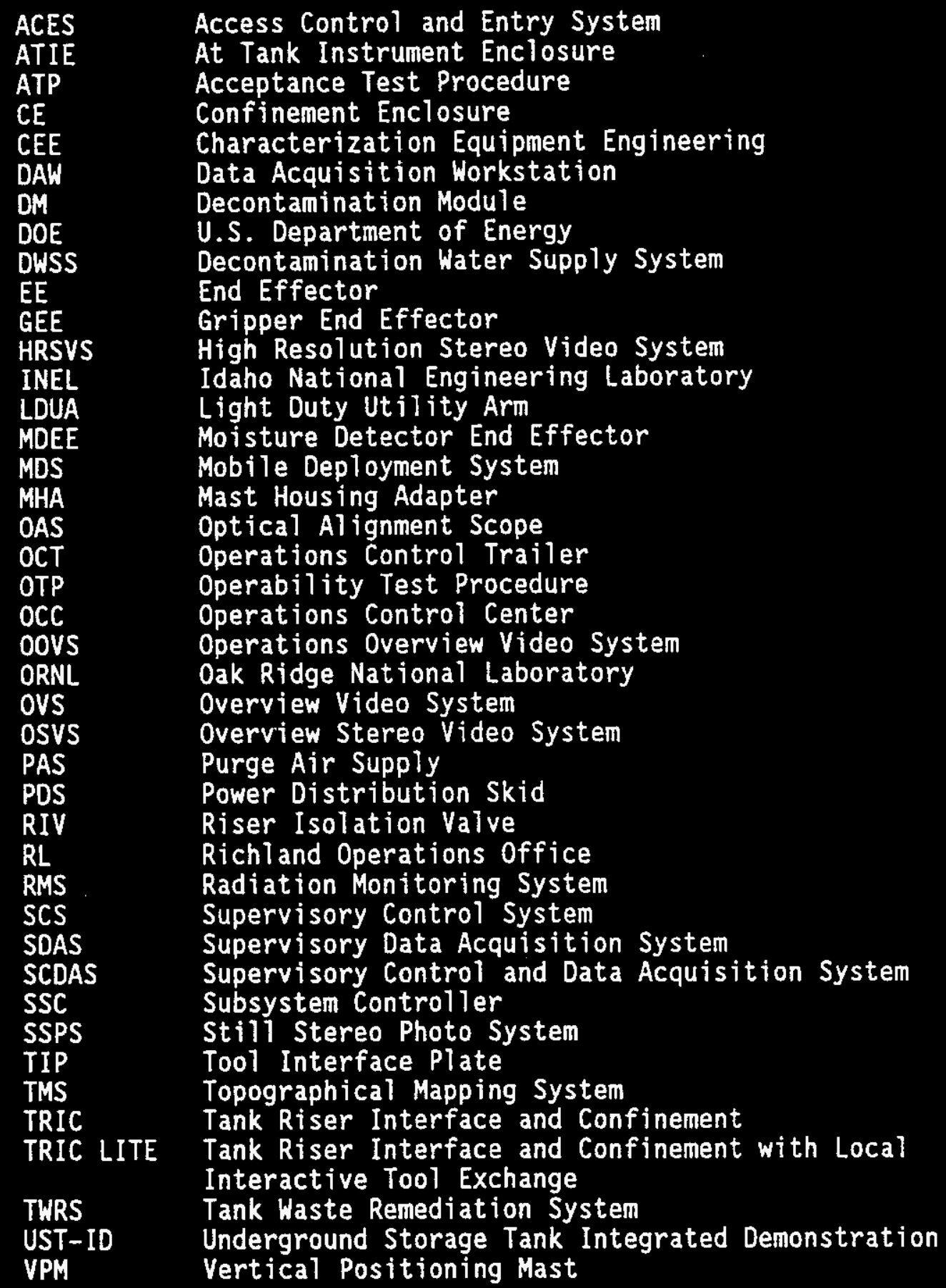


WHC-SD-WM-ETP-176 Rev. 0

\subsection{INTRODUCTION}

\subsection{PURPOSE}

The purpose of this document is to provide an overview of the Light Duty Utility Arm (LDUA) system and to provide a plan for the engineering tasks needed to enable the hot testing of the system at Hanford Site tank T-106. The schedule major objective is to complete all preparations and installation of the system on a selected 12-inch riser by the end of August 1996 and complete the hot testing program and system removal by the end of September 1996. This schedule will require a highly coordinated effort between the organizations shown in Figure 1.1.1. The major work scope, estimated timing and cost for each participant, is identified in Section 4.0.

\subsection{BACKGROUND}

The U.S. Department of Energy (DOE) created the Office of Technology Development (OTD) to assist in the environmental restoration of waste sites across the DOE complex. To support this task, a number of major technology development efforts were initiated. One such effort was the Underground Storage Tank Integrated Demonstration (UST-ID). This development was to concentrate on technologies needed for the remediation of waste tanks.

In 1992, Tank Waste Remediation System (TWRS) senior management requested (Appendix A) that OTD undertake the development of a light duty utility arm that could provide off-riser manipulative, inspection, waste sampling and in situ analytical capabilities to support the Hanford Site waste tank remediatian and closure mission. The DOE Richland Operations Office (RL) reaffirmed this strategy in April 1995 (Appendix B). Hanford is designated the lead DOE site in development and application of this technology. A "Memorandum of Understanding" documenting the division of responsibilities between the Office of Technology Development (EM-50) and Tank Waste Remediation system (EM-30) is included for reference in Appendix C.

Four LDUA systems are presently under construction, two of which will be sited at Hanford, one at the Idaho National Engineering Laboratory (INEL), and one at 0ak Ridge National Laboratory (ORNL). The first unit to arrive at Hanford, scheduled in March 1996, will be qualification tested in June 1996 and subsequently hot tested in September 1996. The second Hanford unit will be used for a period for tooling development in support of all three sites. The INEL and ORNL units will be used in waste tank remediation work at those sites.

\subsection{SYSTEM DEVELOPMENT TURHOVER FOR BENEFICIAL OPERATION}

Figure 1.1.2 summarizes the process for development of the LDUA, and its turnover to Characterization Operations following successful completion of the Operability Test Procedure (OTP) and possible extended hot testing missions. Section 5.0 summarizes the major TWRS milestones for the FY 1996 work. 


\begin{tabular}{|c|c|c|c|c|c|c|c|}
\hline \multirow{4}{*}{$\stackrel{\infty}{\frac{0}{0}}$} & & & & & & əsnoH $\mathbf{d}$ & RpouvoXX M (t \\
\hline & & & & & & sonyod $s$ & कxtureous g (t) \\
\hline & & & & & & zery $\alpha(z$ & 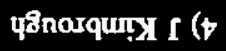 \\
\hline & & & & & & pusqoвg $\alpha$ & 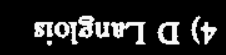 \\
\hline 。 & & & & & mofexna 5 & UosAz?sto y (t) & vorng $f(\varepsilon$ \\
\hline N & & & & & oxd!7 a ( $\varepsilon$ & IoSng $\supset(\varepsilon$ & O8I8A 0 \\
\hline 高 & & & 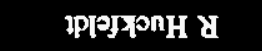 & 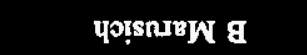 & 4ฐฺnbef 8 & sosuguner y & uosurH $\supset$ ( \\
\hline$c$ & . & & pood $\mathrm{T}(\tau$ & 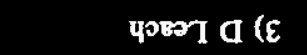 & чाए० $\mathrm{a}$ & sริututer $L$ ( ) & suyor 8 \\
\hline & & & $52008 \mathrm{f}$ & 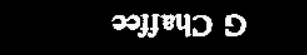 & sser $\alpha$ & stounw!s T (E & 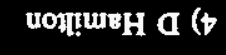 \\
\hline 붕 & 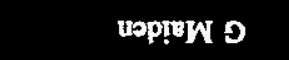 & & IOQ9PM $f(\varepsilon$ & ozuoou & LP[Z]LL d & uamod d & מIIL y \\
\hline 石 & sердатеL $S(\varepsilon$ & & shoqoy I ( $z$ & शquirg $v(z$ & чормоН о & $\prod^{n} \mathrm{H} X$ & pesuoj g \\
\hline & ४⿻甲一nbv $\mathrm{M}$ & 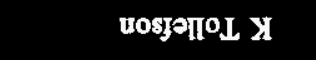 & капеок w & pouvag $\mathbf{X}$ & unarg i $(t$ & Rovfy S ( & Lonvg \& \& $\$$ \\
\hline$\tau$ & Ifossty y ( $\varepsilon$ & uospuerpa g ( $\varepsilon$ & RONEH $t$ & ind a (I & 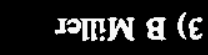 & soppd $\alpha(\varepsilon$ & puourkey y $(\varepsilon$ \\
\hline 总 & uosdepuv ว (Z & 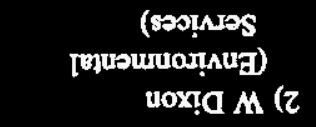 & घ!МנED I ( $z$ & 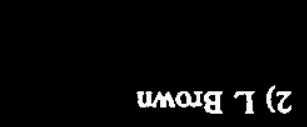 & xown $\perp$ ( $Z$ & sYIM I $(z$ & plowng 7 ( 2 \\
\hline & 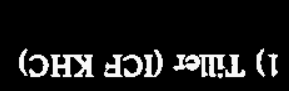 & 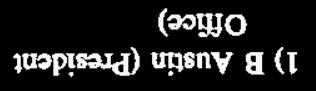 & (Osz) ungens $\alpha$ ( $\mathrm{I}$ & 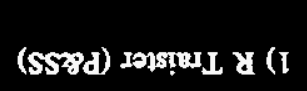 & & & h.L) voseg y (I \\
\hline & & & aาgvi No & SO LSAI LOH & & & \\
\hline
\end{tabular}


WHC-SD-WM-ETP-176 Rev. 0

Figure 1.1.2. Light Duty Utility Arm System Flow Chart.
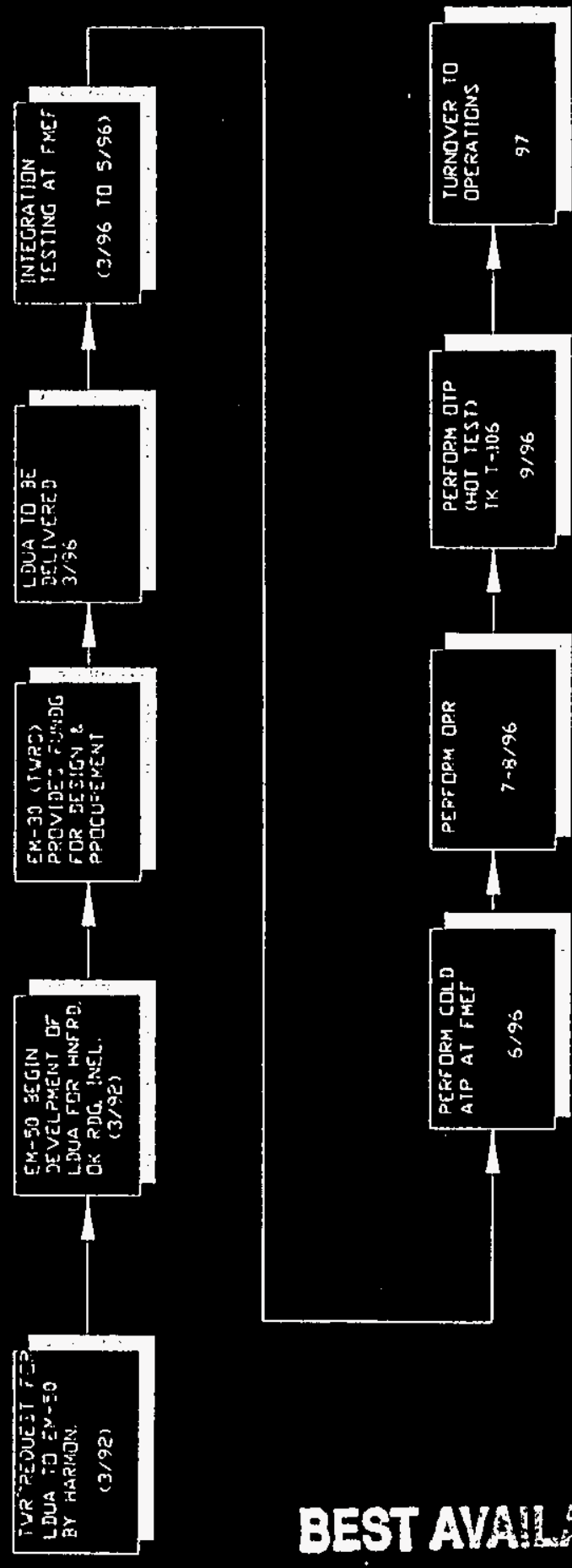

量。

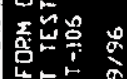

岁要点
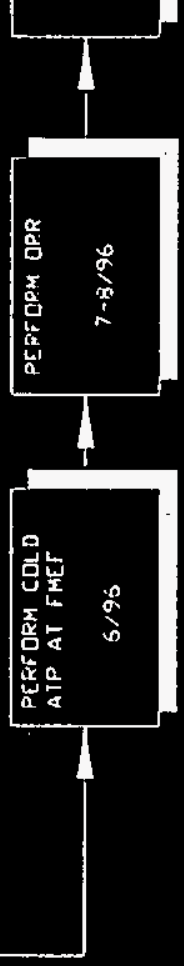

BEST AVAILSTH 
The first LDUA arm, positioning and transport system will arrive at Hanford in March 1996. Following its arrival, it will undergo a two month process of integration with other system components [supervisory controls, tooling (end effector) checkout, and integration].

In June 1996, the integrated system will undergo a cold qualification or Acceptance Test Procedure (ATP) at the Cold Test Facility in the 400 Area. The Operational Readiness Review by the Westinghouse Hanford Company (WHC) and the RL is planned for July and early August and will be based on this testing.

Following the installation of the system at T Farm in August 1996, the system will perform its hot OTP in tank T-106 in early September 1996, and will be removed to controlled storage by the end of that month.

After the hot OTP in September 1996, the Characterization Projects Equipment Engineering group may conduct additional hot test missions during FY 1997.

Transfer of the system to Characterization Project Operations will follow the successful hot testing of the system. A draft Acceptance for Beneficial Use (ABU) is provided in Appendix $D$.

\subsection{SCOPE}

This Engineering Task Plan (ETP) defines the TWRS responsibilities and tasks for the preparations to conduct an operational test of the LDUA system in a Hanford Site waste tank. The operational ownership of the system for the preparation and hot testing activity has been accepted by the. Characterization Project with specific responsibility residing with Characterization Equipment Engineering.

\subsection{DESCRIPTION}

\subsection{OVERVIEN OF LIGHT DUTY UTILITY ARM SYSTEM}

The LDUA System deploys a family of tools, called end effectors (EE), into underground storage tanks by means of a robotic arm on the end of a telescoping mast, and collects and manages the data that they generate. Access into the tank is gained through existing risers. A Mobile Deployment Subsystem (MDS) (Figure 3.1.1) transports the mast and arm between tanks and positions them over a 12-inch tank riser for deployment. Ancillary subsystems support the main deployment equipment, performing such functions as maintaining confinement of the tank atmosphere; decontamination of mast, arm, and end effector; power distribution; and observation of in-tank operations.

The LOUA system is operated from the remote Operations Control Trailer (OCT) located outside the perimeter fence of the tank farm, up to 900-feet from the deployment vehicle. [The LDUA control and data acquisition system has many features designed to help the operator in performing specific tasks with the LDUA. These features include the ability to operate the system in a 
Figure 3.1.1. Mobile Deployment Subsystem.

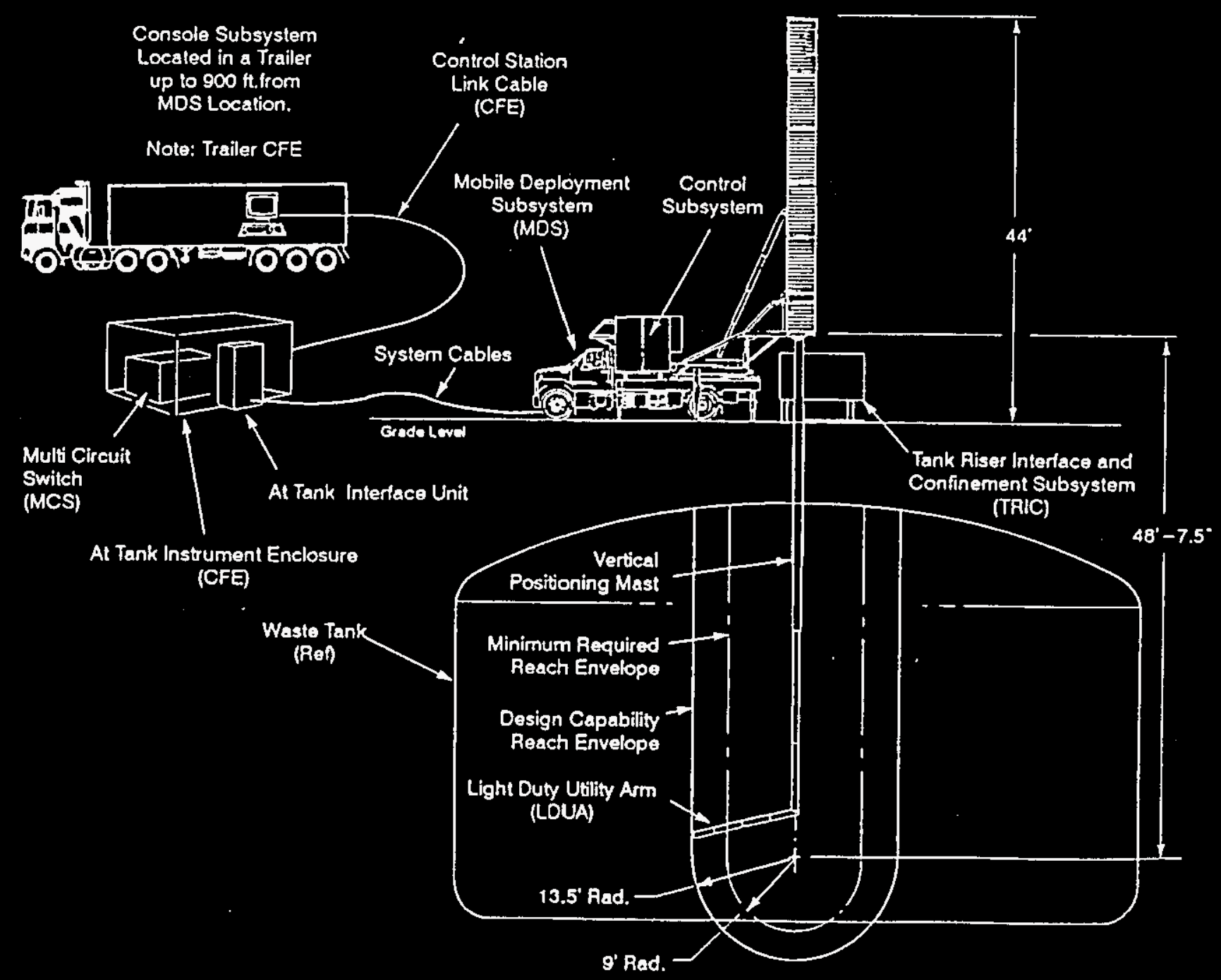


teleoperated (human-in-the-10op) mode as well as under automated control. A three-dimensional (3-D) animated computer graphic model of the arm and the tank is provided to help the operator visualize the motion of the arm, preview paths, and check them for collision.]

The LDUA System provides the capability to reach parts of the tank and waste surface that are not directly under the access risers. This capability has not been available at the Hanford Site before and is one of the primary reasons the LDUA System was developed. The LDUA System is designed to operate safely in the hazardous (high radiation, flammable gases, corrosive chemicals) environment of al1 the 177 underground storage tanks on the Hanford Site as well as underground storage tanks located at other DOE sites. It is also designed to accept new end effectors and adapt to new missions with little disruption to the existing system. The following description of the system and it's operation is excerpted from Kiebel (1995).

\subsubsection{LDUA System Setup}

When a tank has been identified for inspection, plug gauges will be used to verify that the risers chosen for deployment have adequate internal clearance for the LDUA and separately deployed video systems.

Following successful riser gauging, the major equipment systems of the LDUA System will be transported to the tank farm and set up. The OCT (Figures 3.1 .1 and 3.1 .2 ) will be placed outside the tank farm fence. The At-Tank Instrument Enclosure (ATIE) will be placed in the vicinity of the riser chosen for LDUA deployment. The fiber optic umbilical cables will be connected between the ATIE and the OCT. The Power Distribution Skid (PDS) will be placed inside the tank farm near the other equipment and power cables will be connected between it and the main source of 480 VAC (either a portable generator or a temporary substation). Power cables will also be connected between the PDS and the ATIE, and between the OCT and the main power source.

Video viewing systems that are deployed separately from the LDUA will be attached to the risers (typically 4 inches) chosen for their deployment. These systems will have their own riser interface and environmental containment and any necessary local support electronics. They will be connected to the ATIE and will be operated from the OCT.

The Tank Riser Interface and Confinement (TRIC) subsystem will be attached to the riser chosen for deployment of the LDUA. It's decontamination module will be connected, via hoses, to the Decon Water Supply System (DWSS) water trailer.

The LDUA system will be transported to the tank using the MDS (Figure 3.1.3). The MDS will be positioned near the TRIC, and will be connected to the PDS so that its hydraulics can be powered up. The MDS outriggers will be extended to provide a firm base for LDUA deployment. The control pendant attached to the MDS will be used to upend, position, and align the Vertical Positioning Mast (VPM) housing to mate with the TRIC. A contamination control boundary will be established between the TRIC and the VPM housing using a flexible seal and the tank pressure sense line for the purge system will be connected between the TRIC and the MDS. With the mating 
WHC-SD-WM-ETP-176 Rev. 0

Figure 3.1.2. Light Duty Utility Arm System Block Diagram.

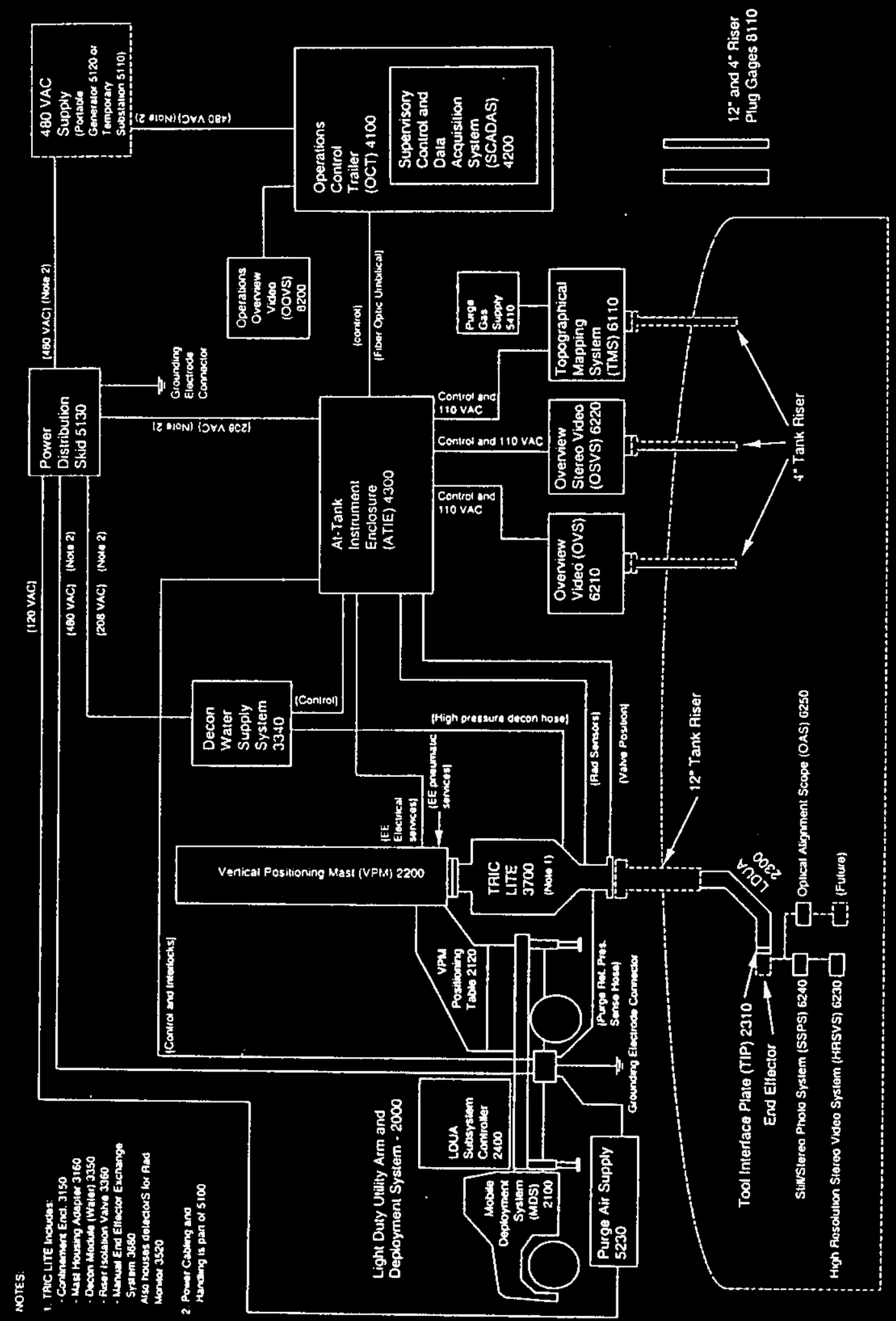


WHC-SD-WM-ETP-176 Rev. 0

Figure 3.1.3. Mobile Deployment System.

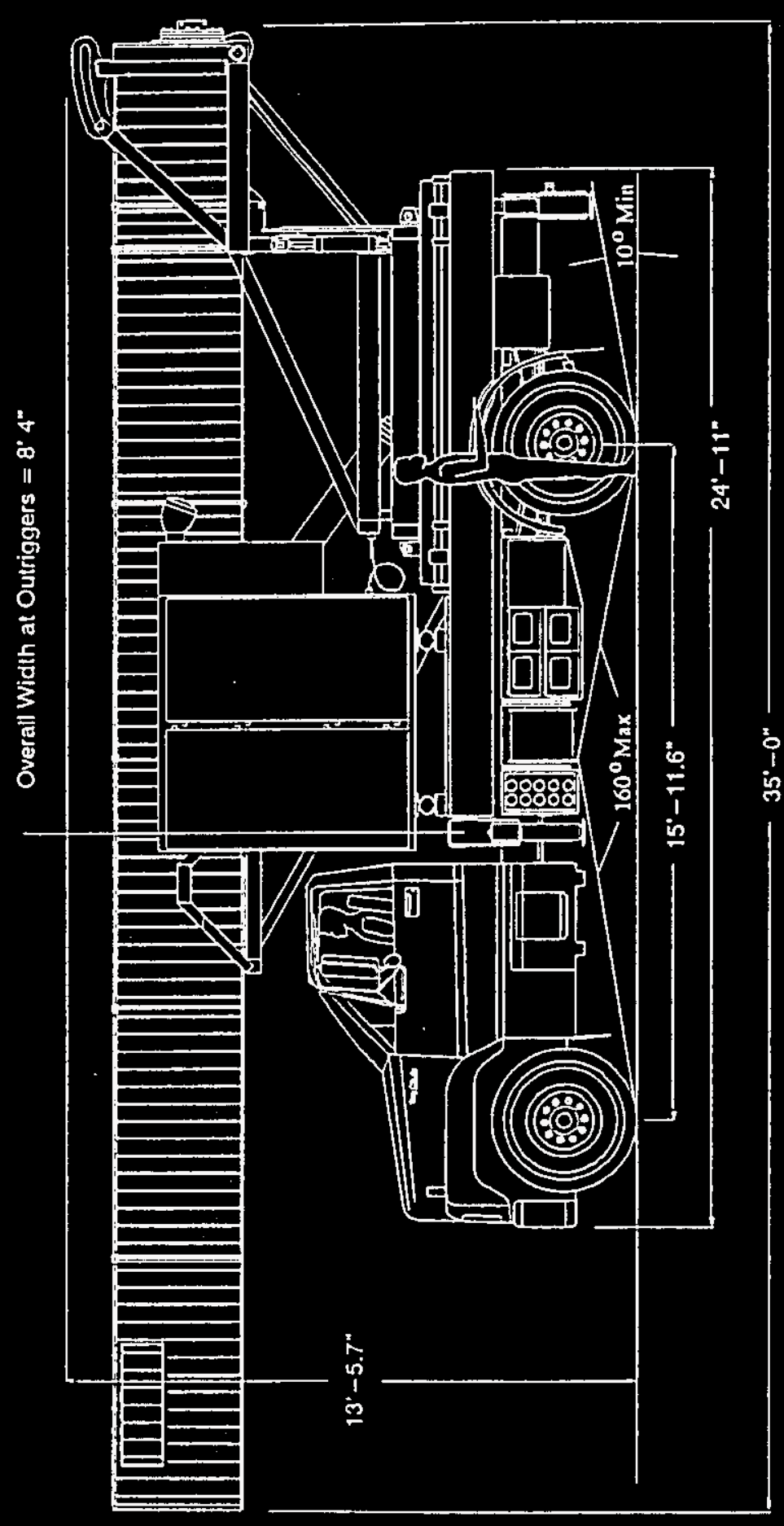


to the TRIC complete, the MDS umbilical will be connected to the ATIE and full control will be transferred over to the supervisory control system inside the OCT. Because some risers may not be absolutely vertical, an optical alignment end effector will be attached to the end of the arm and used to finalize the position of the mast and arm to ensure that they are accurately aligned with the riser.

\subsubsection{System Operation}

To initiate a surveillance, inspection, or characterization campaign, an EE will be selected for the desired operation. The installation of the EE to the arm will be manually accomplished within the TRIC, utilizing a tool change-out mechanism to position the aligned end effector directly below the arm. Following EE attachment, the VPM, LDUA, and EE will be lowered through the TRIC, decontamination module, and riser closure valve into the tank. These operations will usually be performed using the supervisory controller; however, the MDS control pendant can provide simple operation of LDUA and VPM for recovery or maintenance activities.

Operation of the LDUA and EEs inside the waste tank will normally be performed from the $O C F$ using supervisory control (automated sequences) or by teleoperation (human-in-the-10op) using graphic computer displays to monitor and control the equipment, and on-board and overview cameras to provide direct visual feedback to the operator. After lowering the deployment mast to the desired elevation in the tank, the arm will be deployed for positioning end effectors to perform their in-tank functions. End effectors will normally be operated from the OCT using the Supervisory Control and Data Acquisition System (SCADAS), which will also collect the data they generate. It is anticipated that once the system has been depioyed in a waste tank, it will operate in that tank for approximately one to two weeks. During this period, multiple EE change-outs may be performed without removing the mast housing from the TRIC. Normal decontamination of the mast, arm, and EEs will take place during these exchanges as the mast is withdrawn through the highpressure water spray decontamination module.

\subsubsection{System Hierarchy Description}

The LDUA System is organized into a hierarchy with major equipment systems at the top that are subdivided into subsystems. A hierarchical numbering scheme is used to identify systems and subsystems. Below is the 1 ist for the LDUA Baseline System (See Figure 3.1.2).

2000 Arm/Deployment System

2100 Mobile Deployment System (MDS)

2200 Vertical Positioning Mast (VPM)

2300 Light Duty Utility Arm (LDUA)

2310 Tool Interface Plate (TIP)

3000 Tank Riser Interface and Confinement (TRIC) System

3100 Confinement Enclosure

3300 Decontamination System

3500 Miscellaneous TRIC Instrumentation and Control

3600 TRIC Accessories 
4000 Operations Control Center (OCC)

4100 Operations Control Trailer (OCT)

4200 Supervisory Control and Data Acquisition System (SCADAS)

4300 At-Tank Instrument Enclosure (ATIE)

4400 Control Network

5000 Utilities

5100 Electrical Systems

5110 Temporary Substation

5120 Portable Generator

5130 Power Distribution Skid (PDS)

5200 Compressed Gas Systems

5230 Purge Air Supply (PAS)

5400 Miscellaneous Gas Systems

5410 Purge Gas Supply

6000 End Effectors

6100 Tank Mapping Systems

6110 Topographical Mapping System (TMS)

6200 Remote Viewing Systems

6210 Overview Video System (OVS)

6220 Overview Stereo Video System (OSVS)

6230 High Resolution Stereo Video System (HRSVS)

6240 Still/Stereo Photo System (SSPS)

6250 Optical Alignment Scope (OAS)

7000 cold Test Facility

8000 0ther Equipment

8100 Riser Characterization Equipment

8200 Operations Overview Video System (OOVS)

In addition to the baseline end effectors listed above, a gripper end effector (GEE) and a moisture detector end effector (MDEE) are being designed and fabricated for the hot test.

\subsection{ARM/DEPLOYHENT SYSTEM (Figure 3.1.3)}

\subsubsection{Mobile Deployment System (MDS)}

The MDS is based on a flatbed truck and is used to transport the LDUA between and with in tank farms for deployment. The truck has outriggers which extend to provide a firm base for deployment of the mast and arm. The MDS is equipped with an $X Y$ positioning table to which is mounted the vertical positioning mast enclosure and its tip-up mechanisms that allows the enclosure to be elevated to the vertical position for deployment and lowered to the horizontal position for transport. The $X Y$ positioning table also provides fine positioning control of two axes of translation ( $x$ and $y$ ) over a range of 6 inches, and of two axes of tilt (pitch and roll) over a range of 5 degrees. These fine control motions are used to align the axis of motion of the VPM with the riser to assure free passage of the VPM into the tank. The outriggers and the positioning table axes have mechanical locks that can be 
set to prevent slippage once final position has been achieved. The VPM housing has electronic inclinometers that can detect any ground settling or other unwanted motion that may affect the alignment of the VPM to the riser.

\subsubsection{Vertical Positioning Mast $\&$ Housing (VPH)}

The VPM provides the gross vertical positioning of the LDUA within the waste tank. It has infinitely variable speed control from 0 to 15 feet per minute. When fully deployed, the VPM can reach 47 feet below the bottom of the VPM housing (measured at the shoulder pitch joint of the LDUA). This means that the end effector can reach the bottom of the deepest Hanford single-shell tank (nominally 50 feet below grade). The VPM housing provides a sealed contamination boundary in both the deployed and transport modes. It has a standard 14-inch gate valve at the bottom which is closed to seal the housing and opened to allow the mast and arm to extend.

The VPM has two telescoping tubular sections. The LDUA is attached to the bottom of the inner mast tube and both are wholly contained inside the outer mast tube when fully retracted. The mast tubes are made of $304 \mathrm{~L}$ stainless steel.

\subsubsection{Light Duty Utility Arm (LDUA) (Figure 3.1.4)}

The LDUA is a vobotic manipulator that has 7 degrees of freedom that provide dexterity to reach around obstructions in the tank while orientating and positioning end effectors to any surface within its operating envelope. It provides a TIP (2310) at its wrist for mounting interchangeable special purpose tools and instrument packages referred to herein as end effectors. The maximum payload of the arm is 75 pounds with the arm fully extended 13.5 feet in the horizontal position. At the nominal payload of 50 pounds, the LDUA is designed to have a repeatability of \pm 0.2 inch from an established starting point, and a minimum resolution is 0.05 inch. The LDUA is designed to have a positional error of \pm 0.5 inch, and the control system is designed to compensate for static deflection of the VPM under load in order to minimize the end-to-end error of the whole system. The LDUA is constructed almost entirely of 17-4PH stainless steel which provides high strength and corrosion resistance. It is a completely sealed unit that carries all of its wiring and utilities internally. It has flexible boots at each joint to maintain the seal. There is a video camera in the shoulder section of the LDUA that can observe a good portion of the working envelope.

\subsubsection{Tool Interface Plate (TIP)}

The TIP provides a common mounting surface for each of the arm-mounted special purpose end effectors that are used in the underground storage tanks. The interface joint is sealed against the tank atmosphere and contents. The TIP has a set of guide pins that assure proper alignment of the EE assembly and three latches that engage and lock the EE to the arm. A set of electrical and pneumatic service utilities are provided for EE operation. These are routed through connectors within the sealed interior of the TIP. These service utilities includes 30 shielded twisted wire pairs (for signals), 4 shielded triple wire sets (for power), 3 coaxial cables (for video or other high-speed signals), 1 hose (for purging the end effectors), and two hoses 
WHC-SD-WM-ETP-176 Rev. 0

Figure 3.1.4. Light Duty Utility Arm Dexterity.

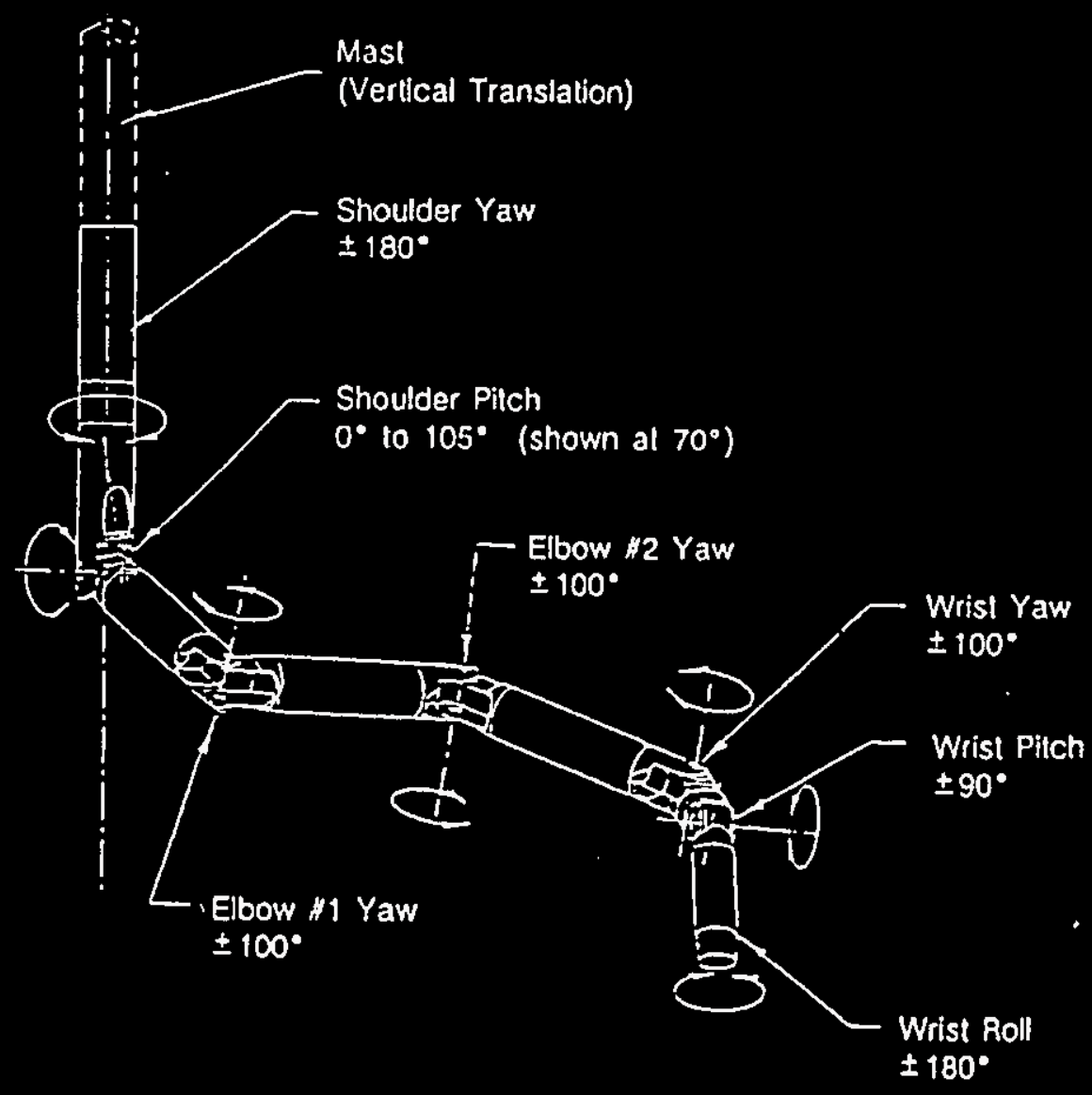


(for powering pneumatic actuators). A six-axis force/torque sensor is provided in the arm's wrist joint. It is not integrated into the control system, but its output is available to be read in the OCT.

\subsubsection{Arm/Deployment System Local Control}

The truck mounted LDUA Subsystem Controller (SSC) provides direct control of the VPM, LDUA, and MDS. It provides a control pendant for 1 imited local operation and interface to the Supervisory Control System (SCS), and LDUA console located in the OCT for remote operations.

The control pendant is attached by a 30-foot tether from the MDS. It is normally used to raise and lower the VPM housing and for gross positioning of the XY table to align the VPM housing to the TRIC for attachment. The pendant can also be used during maintenance to jog each axes of the LDUA, VPM, and MDS.

The LDUA SSC provides several modes of control for the LDUA and VPM. It allows the operator to control each joint of the LDUA and VPM individually.

\subsection{LDUA TO TANK RISER INTERFACE EQUIPNENT}

\subsubsection{Isolation Valve and Spool Piece}

A gate type Riser Isolation Valve (RIV) will mount to the 12 -inch riser flange to provide environmental and staff protection during the balance of the LDUA system installation and during manual operations within the TRIC such as EE changing. The valve is sized to enable the LDUA and VPM to pass through when it is fully open.

A replaceable spool piece mounted between the isolation valve and decontamination module (DM) will enable adaptation for varying riser flange elevations relative to the ground level.

\subsubsection{Decontamination Module and Radiation Monitor}

The Water DM (3350) provides for gross removal of external contamination from the mast and arm by spraying high pressure water (up to 500 psi) onto them as they are withdrawn from the tank. This module normally remains attached to the bottom of the confinement enclosure. The RIV (3360) mounts between the riser and the DM. It has a quick-disconnect joint which simplifies installation of the TRIC onto the riser. The valve is separable from the TRIC and installed first onto the riser flange. This allows good access to the flange bolts and the valve subassembly is easier to handle than the whole TRIC. When the valve is secured, the TRIC is moved into position and locked into place with the quick-disconnect joint.

The DM provides a sealed chamber which contains a spray ring that provides 360 degree coverage of the outer surface of the segment of the VPM, LDUA, or EE that is inside the module. Water and dislodged contamination return to the tank via the riser. A flexible splash barrier is provided between the DM and the TRIC as a barrier to contaminated spray. This splash barrier can be tilted up to allow a clear line of sight into the riser that is necessary for the alignment process. The DWSS (3340) supplies pressurized 
water to the DM via a hose that is attached by a double-end shutoff quickdisconnect fitting.

A Radiation Monitor Subsystem (RMS) (3520) is provided that is sensitive to the gross gamma radiation levels within the DM. It provides a first order quality check on the effectiveness of the decontamination process. Four Geiger-Mueller (GM) tube type detectors are installed in shield assemblies in four detector wells that are provided in the DM. The shield assemblies provide windows that face toward the center of the module. Altogether, the detector/shield array provides 360 degree coverage of the outer surface of the part of the LDUA, VPM, or EE that is inside the DM, and it provides a preferential sensitivity to radiation from that source and rejection of background radiation. The readout electronic for the detectors are housed in the ATIE.

\subsubsection{Tank Riser Interface Confinement (TRIC) Module}

The TRIC provides an interface between the LDUA system and the waste tank riser. It is used for change-out of EE, minor maintenance tasks, and containment of the tank atmosphere. A decontamination system is provided for routine cleaning of the arm and deployed EE. The particular configuration of TRIC used for the Baseline LDUA System is defined as subsystem 3700, or Tank Riser Interface and Confinement with Local Interactive Tool Exchange (TRIC LITE). In this document, the term TRIC is synonymous with TRIC LITE. It is a very simple design which is 1 ight enough to bolt directly to the deployment riser. This makes it self-aligning and eliminates the need for adjustments.

The Confinement Enclosure (CE) (3150) provides radiological confinement when the access riser is open, such as when the LDUA is deployed into the tank. Several sets of gloveports are provided to allow minor hands-on activities to be performed on the LDUA or the end effector. A large door on the side of the enclosure provides access for the exchange of end effectors on the arm.

The Mast Housing Adapter (MHA) (3160) provides a flexible sealed coupling between the top of the confinement enclosure and the bottom of the VPM Housing. Flexibility is necessary to compensate for the variations in height that are expected to occur from one deployment to another because of different riser elevations and different ground surface contours. Flexibility is also necessary to allow for the movement of the VPM Housing during the process of aligning it to the riser at initial installation.

\subsubsection{Manual End Effector Exchange System}

The Manual End Effector Exchange System (MEEES) (3660) assists the operator in mounting and dismounting EE to and from the LDUA wrist. 


\subsection{LDUA SYSTEM BASIC TOOL KIT}

\subsubsection{Overview Stereo Video System}

The Overview Stereo Video System (OSVS) (6220) is deployed through a 4-inch riser and provides a pair of radiation tolerant color cameras that are aligned to generate video signals that can be combined into a stereoscopic image by a signal processing module.

\subsubsection{Overview Video System}

The Overview Video System (OVS) (6210) provides a single black and white radiation hardened camera which is inserted down a 4-inch riser away from the riser on which the LOUA system is mounted. The camera provides on overview of the LDUA operations to the control trailer (OCT).

\subsubsection{High Resolution Stereo Video System End Effector}

The High Resolution Stereo Video System (HRSVS) (6230) is an end effector package that mounts on the arm's TIP. The system is designed to enable closeup stereo viewing of such things as waste tank wall welds and possible tank or weld cracks.

\subsubsection{Gripper End Effector}

The Gripper End Effector (GEE) mounts to the arm TIP and provides a pneumatically-actuated parallel jaw gripper for manipulation of items within the tank. The GEE grip force is variable from 50 to 200 pounds. The parallel jaws open approximately 5-6 inches. The lifting capability of the arm and GEE is established at 30 to 40 pounds, with the arm fully extended in the horizontal position. A small video camera in the GEE enables close viewing of objects to be handled.

\subsubsection{In Situ Moisture Detector End Effector}

The Moisture Detector End Effector (MDEE) will also mount to the arm TIP and will provide a neutron source based instrument package for in situ, offriser measurement of surface layer moisture content.

\subsubsection{Surface Sampier End Effector}

A Surface Sampler End Effector (SSEE) is being designed that will mount to the arm TIP and will provide a pneumatically- (or electrically-) driven auger for taking 50 to 100 gram samples in the top 12 inches of the sait or heavy sludge tank waste. The device will not be available for the system OTP.

\subsubsection{Topographical Mapping System}

The Topographical Mapping System (TMS) $(6110)$, is inserted into a tank through a 4-inch riser, uses laser light to accurately measure the interior surfaces of the tank structures and waste. Measurements are taken on a rectangular grid by an automatic scanning process. Contour maps of the scanned surface are generated. The TMS has its own on-board computer and is completely autonomous. It communicates with the Supervisory Data Acquisition 
System (SDAS) using the control network to which it connects via a fiber optic link to the ATIE. The operator controls the TMS via a control screen on the Data Acquisition Workstation (DAW). It is commanded to make a scan, or series of scans, and the finished surface map data is placed in data files than can be read by SDAS.

\subsubsection{Riser Characterization Equipment}

Plug gauges are used for verifying that there is a sufficiently clear path through a riser for LDUA equipment to pass without binding. There is a plug gauge for 4-inch risers and one for 12-inch risers. The plug gauges are designed to be lowered into the risers by crane. They are each provided with water spray nozzles at the bottom end that are used to spray the inside of the riser in order to reduce to potential for contamination.

\subsubsection{Optical Alignment Scope}

The Optical ATignment Scope (OAS) (6250) mounts on the end of the arm in place of and EE and is used for aligning the VPM to the deployment riser.

\subsection{OPERATIONAL SUPPORT EQUIPIENT}

\subsubsection{Power Distribution Skid}

The LDUA System is powered from a 480 VAC, three-phase power supply and it requires approximately $175 \mathrm{KVA}$. This power supply can be either a portable generator (5120) or a temporary substation (5110) at the tank farm. The power source feeds the OCT (4100) and the PDS (5130). The PDS, which is placed inside the tank farm near the other LDUA equipment, reduces the 480 VAC main supply power to 208Y/120 VAC for use by the LDUA at-tank equipment. Power is transmitted into the tank farm at 480 VAC to reduce the number and size of the power cables that must be handled. The PDS also provides circuit breakers and other protective features required by the National Electric Code (NEC). The power cables that connect to the PDS to the main power supply are physically bulky and heavy. They have been supplied in 100-foot and 200-foot sections that are more easily handled. The sections are provided with connectors that allow then to be hooked together as needed.

\subsubsection{At Tank Instrument Enclosure}

The ATIE houses the support electronics for the end effectors that must be as close as possible to the end effector (the ATIE is located within 50 feet of the (DUA). This enclosure is weather tight with heating and cooling to maintain internal temperature between 50 and $95^{\circ} \mathrm{F}$ during operation. Standard 19-inch racks are provided for mounting of EE support equipment. Standard 110 VAC power is provided for equipment.

A11 LDUA mounted EEs share the common set of service utilities provided at the TIP. A patch panel in the ATIE allows them to be manually switched to the appropriate support electronics when a particular end effector is mounted on the TIP. 
WHC-SD-WM-ETP-176 Rev. 0

\subsubsection{Operations Control Traiter}

The OCT is a 48-foot standard semi-trailer that is towed to the tank farm and parked outside the perimeter fence. The OCT has an air suspension system to provide a smooth ride for the equipment it houses, and it is fitted with jacks to level and stabilize it when parked. The OCT has thermostatically controlled forced air heating, ventilation and air conditioning (HVAC) system. It is powered from a 480 VAC supply (see Section 3.5 .5 ) and it has a complete power distribution system to supply its integral lighting and HVAC needs, and to provide 110 VAC power to the electronic equipment that it houses. The layout of the OCT provides two separate work areas: the operating area contains the control panels and workstations that control the LDUA System; the visitor area has desks, shelves, data access workstations, and other amenities for people who are involved in analyzing data or planning the next activity.

All control and data signals to and from the OCT pass through a fiber optic umbilical cable which is connected between the OCT and the ATIE. This cable carries many individual fibers (glass, 62.5 micron, multi-mode) that are used by the LDUA SSC and the EEs to communicate with their support electronics in the OCT. The fiber optic umbilical cable is small, lightweight, and rugged. It is impervious to electromagnetic interference and is capable of carrying signals over a much longer distance than the required 900 feet.

The LDUA control and data acquisition system is divided into a supervisory level and a subsystem level. The subsystem level provides for basic equipment operation and each LDUA subsystem has its own controller. The supervisory level provides most of the integration and coordination between the mast and arm, the EES, and the ancillary equipment. The SCS directs the LDUA and VPM and the SDAS directs the EES and some of the ancillary equipment subsystems such as the TRIC.

The LDUA system is designed to be operated remotely by two operators in the OCT using computer workstations. The arm operator is responsible for operating the deployment subsystems (mast, arm, etc.), and the EE operator is responsible for operating the end effectors and collecting data. [A safety feature of the control system prevents simultaneous control from the OCT and local panels at the riser.]

The operations workstation provides a 3-D animated graphic display for visualizing the operation of the mast and arm. The operator may preview motion of the arm in simulation using any of the motion control modes that the system provides. If the motion is acceptable and collision-free, the operator is given the option of having the system execute it as it was simulated.

The LDUA console works in conjunction with the operations workstation. It provides display and access to the detailed status and operating parameters of the LDUA Subsystem controller. Hand controllers (such as joysticks) are connected to the LDUA console for teleoperation of the mast and arm.

The DAW provides the primary user interface for operating EEs, collecting data, and for monitoring and controlling the TRIC environment subsystems. It provides a single point from which data can be acquired, processed, and stored. 
There are many video cameras in the LDUA System, including units on the arm, in EEs, and in the ancillary equipment. The video display and recording subsystem provides monitors and VCRs to display and record video information from these cameras. All aspects of video switching and display and recording are controlled by the DAW, including the video cameras, the routing of signals, the VCRS, and the overlay of titles and other selected information onto the video.

The auxiliary workstation provides the ability to obtain information from the system without disturbing the operators at the primary workstations. It is located in the rear area of the OCT away from the operating area. Printers, plotters, and other peripheral devices are also located in this area.

\subsubsection{Décon Water Supply System}

The decon water supply system (DWSS) for the DM (Paragraph 3.2.2) is trailer mounted and has a storage tank (500 gallon), and a pump. An umbilical cable connects the supply unit to the ATIE (Paragraph 3.5.2) to allow the LDUA decontamination spray to be remotely controlled and monitored.

\subsubsection{Engine/Generator}

The diesel generator will be provided by TWRS (see responsibilities section). The total required output is $175 \mathrm{KVA}$ at $480 \mathrm{VAC}, 3$-phase. The output is fed to the LDUA system via four breakers and connectors. The breaker ratings and loads are the following:

$$
\begin{aligned}
& \text { OCT - 100A, 480V, 3-phase, } 100 \% \text { rated (breaker rating may be changed in } \\
& \text { near future?) } \\
& \text { ATIE- 20A, 480V, 3-phase } \\
& \text { Misc Loads - 60A, 480V, 3-phase } \\
& \text { LDUA Vehicle - 90A, 480V, 3-phase }
\end{aligned}
$$

\subsubsection{Tank Exhauster}

A tank exhauster was originally planned to be required during operation of the LDUA. However, several design changes have occurred which el iminate the LDUA system requirement for a tank exhauster. Therefore, there is currently no plan to use an exhauster for the initial hot oTP deployment. As a contingency however, and to support post turnover operations, an air permit for SST's will be obtained.

\subsection{AUDIO AND VISUAL CONHUNICATIONS EQUIPMENT}

\subsubsection{Field Audio Communications}

Field audio communications between the OCT and personnel working within the tank farm boundary at the riser will be via radio-based equipment like that now commonly used. 


\subsubsection{Visual Communications}

The Operations Overview Video System (OOVS) provides the operators inside the OCT with a means of viewing the tank farm. This system has a video camera equipped with a zoom lens and a pan/tilt mounting that is set up outside the tank farm perimeter fence near the trailer. The operators can control the camera and can display its output on their video monitors inside the OCT.

\subsection{ORGANIZATIONS AND MANPOWER ESTIMATES}

\section{$4.1 \mathrm{DOE} / \mathrm{RL}$}

DOE Richland Operations office (RL) will be asked for the following support for the LDUA hot test program:

(1) Provide program guidance and direction.

(2) Approve the Plan of Action which provides the strategy for conduct of the Operational Readiness Review preparation and implementation.

(3) Secure timely Headquarters ESQ approval of the ORR process in accordance with DOE Order 5408.31, where required.

\subsection{CHARACTERIZATION PROJECT (L. F. Ermold, Mgr)}

4.2.1 Characterization Operations (J. G. Burton, Mgr, 75100)

4.2.1.1 Production Control and Maintenance Mechanical Readiness (J.A. Kimbrough, Mgr, 75110)

Function: Prepare LDUA Field Test Work Plans

Scooe of Work: 1) Prepare field work plans for tank farm activities.

\begin{tabular}{|c|c|c|c|c|c|c|c|c|c|c|c|c|c|c|c|}
\hline \multicolumn{16}{|c|}{ FY 1996 - Manhours } \\
\hline & 0 & $N$ & D & $\mathrm{J}$ & $F$ & M & A & $M$ & $\mathbf{J}$ & $J$ & A & $s$ & $\begin{array}{l}\text { TOTAL } \\
\text { (hrs) } \\
\end{array}$ & $\begin{array}{l}\text { RATE } \\
\text { S/HR } \\
\end{array}$ & $\begin{array}{l}\text { "TOTAL } \\
s\end{array}$ \\
\hline $\begin{array}{l}\text { Tank inspection } \\
\text { work plan }\end{array}$ & & & 16 & 32 & 16 & & & & & & & & 64 & 57 & 3,648 \\
\hline $\begin{array}{l}\text { Hot Test } \\
\text { instal lation } \\
\text { work plan }\end{array}$ & & & & & & 16 & 40 & 40 & 60 & 40 & & & 196 & 57 & 11,172 \\
\hline Total & & & & & & & & & & & & & 0 & & 14,820 \\
\hline
\end{tabular}

*Rates and cost totals on this and subsequent tables are fully burdened. 


\begin{tabular}{|c|c|c|c|c|c|c|c|c|c|}
\hline $\overrightarrow{\mathrm{E}}$ & 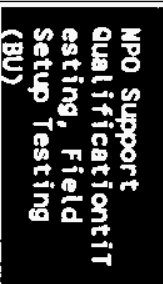 & 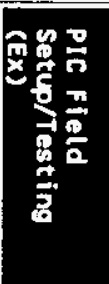 & 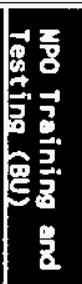 & 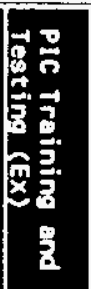 & 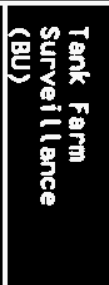 & 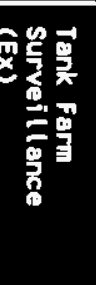 & 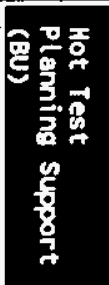 & 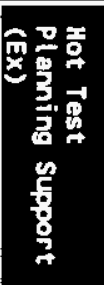 & \\
\hline & & & & & & & & & 0 \\
\hline & & & & & & & & & $=$ \\
\hline & & & & & & & & & 0 \\
\hline & & & & & & & $\infty$ & $\vec{N}$ & c \\
\hline & & & & & & $\vec{a}$ & & & $\pi$ \\
\hline & & & & & $\delta$ & $\approx$ & & & x \\
\hline & & & $\tilde{\tilde{\Delta}}$ & $\overrightarrow{\mathrm{g}}$ & & & & & $>$ \\
\hline & & & $\tilde{\delta}$ & $\vec{\delta}$ & & & & & x \\
\hline & & & $\tilde{\tilde{\delta}}$ & $\overrightarrow{\mathrm{g}}$ & & & & & c \\
\hline & $\mathbb{్}$ & $\overrightarrow{\mathbf{g}}$ & & & & & & & - \\
\hline & 8 & $\overrightarrow{\mathbb{\S}}$ & & & & & & & $>$ \\
\hline & \% & జ్ & & & & & & & $\infty$ \\
\hline & $\overrightarrow{\dot{H}}$ & $\mathbf{E}$ & 종 & 8 & $\hat{\delta}$ & s & $\infty$ & $\vec{N}$ & 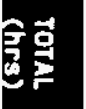 \\
\hline & $F$ & $y$ & 5 & $y$ & 5 & $y$ & 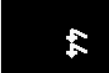 & $y$ & 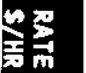 \\
\hline 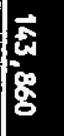 & 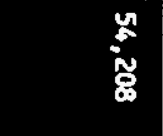 & $\frac{\pi}{\ddot{y}}$ & $\frac{\breve{y}}{\bar{\delta}}$ & $\tilde{z}$ & $\overrightarrow{\vec{z}}$ & 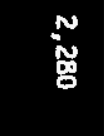 & $\ddot{~}$ & 䙵 & 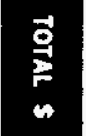 \\
\hline
\end{tabular}
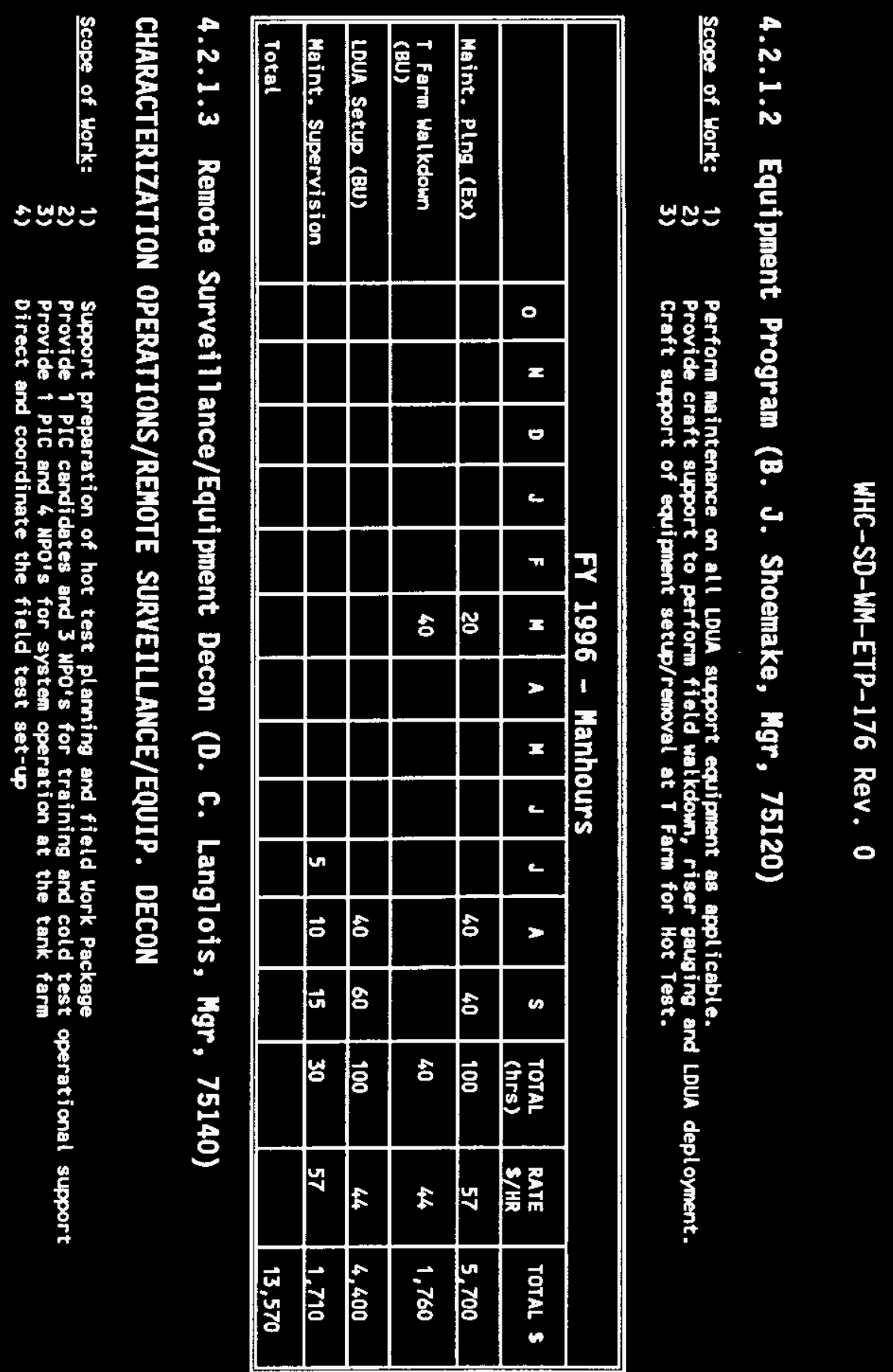


\subsubsection{Characterization Equipment Engineering (R. E. Raymond, Mgr, 75200)}

\subsubsection{Characterization Monitoring Development (R. E. Bauer, Mgr, 75240)}

\section{Function: TWRS Mechanical Design Authority}

Scope of York: 1) Has overall responsibility and is central point of contact for all matters concerned with a successful initial deployment of the LOUA.

2) Take over as mechanical desion authority for TMRS LDUA systen at end of qualification testing at cold test facility.

3) Ensure that all EH-50 design and design documentation is in accordance with TWRS cheracterization requirentents prior to qual ification testing.

4) Provide review and approval of all EM-30 generated design documentation.

5) Shall participate in all phases of LDUA training and shall be fully certified to cperate the LoUA.

6) Prepare hot test plan for OTP.

Function: Electrical Design Agent

Scope of Hork: 1)

2) Ensure that all EM-50 design and design documentation is in accordance with TWRS characterization requirements prior to qualification testing.

Provide revieu and approval of all EM-30 generated design documentation.

shall participate in all applicable phases of LOUA training.

Obtain a generator that will support cold and hot testing. Analyze cost/benefits of new generator, leased generator, and repackaging of PUREX energency generator. Ensure all generator interfaces with LDUA equipment are correct.

\section{Function: TWRS Software/Instrument Design Agent}

Scope of Mork: 1 )

Take over as software design authority for TMRS LDUA systen at end of qualification testing at cold test facility.

2) Ensure that all EM-50 desian and desian documentation is in accordance with TMRS characterization requirenents prior to qual ification testing.

3) Provide revieu end approval of all EN-30 generated design documentation.

4) Shall participate in all applicable phases of LDUA training.

5) Shall ensure all changes to software from start of qualification testing is per wic standard engineering practices.

6 Act as energency DA backup for LDUA hot test with G. R. Kiebel.

\begin{tabular}{|c|c|c|c|c|c|c|c|c|c|c|c|c|c|c|c|}
\hline & & & & & & $\mathbf{Y}$ & 6 & ar & urs & & & & & & \\
\hline & 0 & N & D & J & $F$ & $\mathbf{M}$ & $\boldsymbol{A}$ & M & $d$ & $J$ & $A$ & $\mathbf{s}$ & $\begin{array}{l}\text { TotAL } \\
\text { (hrs) }\end{array}$ & ${ }_{S / h}^{* R A T E}$ & TOTAL $s$ \\
\hline $\begin{array}{l}\text { Mechanical } \\
D A(E x)\end{array}$ & 40 & 120 & 160 & 160 & 160 & 200 & 160 & 160 & 200 & 160 & 160 & 208 & 1,888 & 57 & 107,616 \\
\hline $\begin{array}{l}\text { Soft/Inst DA } \\
\text { (Ex) }\end{array}$ & & & & & & & & & 100 & 80 & 80 & 104 & 364 & 57 & 20,748 \\
\hline $\begin{array}{l}\text { Drafting } \\
\text { Sugort }\end{array}$ & & & & & 110 & & & & & & & & 110 & 60 & 6,600 \\
\hline $\begin{array}{l}\text { Electrical } \\
\mathrm{DA}(\mathrm{Ex})\end{array}$ & & & 10 & 10 & 20 & 5 & 5 & 20 & 40 & 20 & 10 & 20 & 160 & 57 & 9,120 \\
\hline $\begin{array}{l}\text { Electrical } \\
\text { material }(*)\end{array}$ & & & & & & & & & & & & & & & 10,000 \\
\hline $\begin{array}{l}\text { Prepare } \\
\text { oparating } \\
\text { procedures }\end{array}$ & & & & & 320 & 400 & 320 & 320 & & & & & 1,360 & 57 & 77,520 \\
\hline $\begin{array}{l}\text { Procedure } \\
\text { materials }\end{array}$ & & & & & & & & & & & & & & & 2,000 \\
\hline Total & & & & & & & & & & & & & & & 233,604 \\
\hline
\end{tabular}

*All rates include DOH and GRA. 
4.2.2.2 Characterization Equipment Development (C. E. Hanson, Mgr, 75250)

Function: Surface Moisture End Effector Design Agent

Scope of Uork: 1) Prepare task plan for the SMEE.

2) Prepare prel iminary design media (drawings and specifications)

3) Support procurement of standard and contract hardware

4) Direct the equipment assembly and test ing

5) Provide testing, training, operating and maintenance docunents

\begin{tabular}{|c|c|c|c|c|c|c|c|c|c|c|c|c|c|c|c|}
\hline & 0 & $\mathbf{N}$ & D & J & $\boldsymbol{F}$ & $\mathbf{M}$ & $\boldsymbol{A}$ & $\boldsymbol{n}$ & 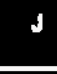 & $\mathbf{J}$ & $A$ & $\mathbf{s}$ & $\begin{array}{l}\text { TOTAL } \\
\text { (hrs) }\end{array}$ & $\begin{array}{l}\text { RATE } \\
\text { S/HR }\end{array}$ & $\begin{array}{l}\text { TOTAL } \\
S\end{array}$ \\
\hline Eng. Task Plan (Ex) & & & & 80 & & & & & & & & & 80 & 57 & 4,560 \\
\hline $\begin{array}{l}\text { Design Requirenents } \\
\text { Document }\end{array}$ & & & & & 80 & & & & & & & & 80 & 57 & 4,560 \\
\hline Testing Procedures & & & & & & 20 & 40 & & & & & & 60 & 57 & 3,420 \\
\hline Doc and training & & & & & & 120 & & & 40 & & & & 160 & 57 & 9,120 \\
\hline Testing Reports & & & & & & & & & 40 & & & & 40 & 57 & 2,280 \\
\hline Total & & & & & & & & & & & & & 0 & & 28,500 \\
\hline
\end{tabular}

\subsection{TANK FARMS TRANSITION PROJECTS (J. H. Wicks, Mgr, 77000)}

\subsubsection{West Tank Farm Transition Project (D. P. Reber, Mgr, 77200)}

The Manager of Tank Farm Transition Project will be responsible for approving the Plant Readiness Team final report and it's submission to the ORR Team.

4.3.1.1 WTF Field Operations (P. L. Owen, Mgr, 77210). WTF Field Operations will maintain an operational cognizance of the hot testing preparations and implementation.

4.3.1.2 WF Plant Engineering (S. H. Rifaey, Mgr, 77240). The T Farm Cog Engineer will be responsible for coordinating planned activities at the tank farm to assure orderly scheduling of the LDUA activities with other operations and projects. He will be a major participant on the Plant Readiness Team and the review and verification of documents for ORR review.

\section{WEST TAWK FARM TRANSITION PROJECT}

Scope of Mork: 1) Tank Farm access planning and scheduling.

2) Participation as working menber of Plant Readiness Tean (time shows on PRT table, Section 4.10).

3) Observational oversite of scheduled work.

\begin{tabular}{|c|c|c|c|c|c|c|c|c|c|c|c|c|c|c|c|}
\hline \multicolumn{16}{|c|}{ FY 1996 - Manhours } \\
\hline & 0 & N & D & $J$ & $\mathbf{F}$ & n & $A$ & n & $\mathbf{J}$ & $J$ & $\boldsymbol{A}$ & $\mathbf{s}$ & $\begin{array}{l}\text { TOTAL } \\
\text { (hrs) }\end{array}$ & $\begin{array}{l}\text { RATE } \\
\text { S/HR }\end{array}$ & TOTAL $s$ \\
\hline $\operatorname{Cog}$ Engr (Ex) & & & & 16 & 16 & 24 & & & & & 16 & 24 & 96 & 57 & 5,472 \\
\hline Total & & & & & & & & & & & & & & & 5,472 \\
\hline
\end{tabular}




\subsubsection{Environmental Cleanup/Compliance Project (C. J. Geier, Mgr, 77500)}

4.3.2.1 Environmental Engineering (R. D. Gustavson, Mgr, 77530)

Scope of York: 1) Prepare non tank specific radioactive particulate emission estimate (use analysis of past head gas seupl ing HEPA filters to provide $r$ nontank specific emission est imate) for the air permit application.

\begin{tabular}{|c|c|c|c|c|c|c|c|c|c|c|c|c|c|c|c|}
\hline \multicolumn{16}{|c|}{ FY 1996 - Manhours } \\
\hline & 0 & N & D & J & $\mathbf{f}$ & M & $A$ & $\mathbf{M}$ & $\mathbf{J}$ & J & $\mathbf{A}$ & $\mathbf{s}$ & $\begin{array}{l}\text { TOTAL } \\
\text { (hrs) }\end{array}$ & $\begin{array}{l}\text { RATE } \\
\text { S/HR }\end{array}$ & TOTAL $s$ \\
\hline Data Prep & & & 80 & & & & & & & & & & 80 & 57 & 4,560 \\
\hline Total & & & & & & & & & & & & & 0 & & 4,560 \\
\hline
\end{tabular}

4.3.3 Training \& Procedures (L. E. Simmons, Mgr, 77700)

\subsubsection{Maintenance/Technical Support Training (P. Jennings, 77710)}

\section{TRAININE}

Scope of Hork: 1) Review vendor suppl ied and EM-50 supplied osM manuals and procedures.

2) Participate in EN-50 provided training and that provided by vendor (SPAR Aerospace).

3) Prepare work plan for integration of operating and training procedure preparation.

4) Prepare training plan and training manul that will include the input from vendor operations and maintenance documents and will reflect the requirements of the schedule.

5) Conduct training and operator qual ification.

\begin{tabular}{|c|c|c|c|c|c|c|c|c|c|c|c|c|c|c|c|}
\hline & 0 & N & D & $d$ & $F$ & M & $\boldsymbol{A}$ & M & $\mathrm{J}$ & $\mathbf{J}$ & $\boldsymbol{A}$ & $\mathbf{s}$ & $\begin{array}{l}\text { TOTAL } \\
\text { (hrs) }\end{array}$ & $\begin{array}{l}\text { RATE } \\
\text { S/HR }\end{array}$ & $\begin{array}{l}\text { TOTAL } \\
\$\end{array}$ \\
\hline Prepare Mork Plan & & & & & 40 & & & & & & & & 40 & 57 & 2,280 \\
\hline $\begin{array}{l}\text { Training Plan/ } \\
\text { manual/classes } \\
\text { (Ex) }\end{array}$ & & & & & 160 & 200 & 160 & 160 & 200 & & & & 880 & 57 & 50,160 \\
\hline Materials & & & & & & & & & & & & & & & 1,000 \\
\hline Total & & & & & & & & & & & & & & & 53,440 \\
\hline
\end{tabular}

\subsection{TWRS ENGINEERING}

\subsubsection{SAFETY ENGINEERING}

\subsubsection{Safety Engineering Program (G. T. Dukelow, Mgr, 74210)}

Scope of Hork: 1) Provide progran guidance and support.

\begin{tabular}{|c|c|c|c|c|c|c|c|c|c|c|c|c|c|c|c|}
\hline \multicolumn{16}{|c|}{ FY 1996 - Manhours } \\
\hline & 0 & $x$ & D & $\checkmark$ & $F$ & 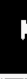 & 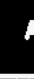 & n & J & $\mathbf{J}$ & $A$ & $\mathbf{s}$ & $\begin{array}{l}\text { TOTAL } \\
\text { (hrs) }\end{array}$ & $\begin{array}{l}\text { RATE } \\
\text { S/HR }\end{array}$ & TOTAL $\$$ \\
\hline Program Adu./support & & & 20 & 16 & 16 & 2 & 1 & 16 & 20 & 16 & 16 & 20 & 176 & 59 & 10,384 \\
\hline Total & & & & & & & & & & & & & & & 10,384 \\
\hline
\end{tabular}




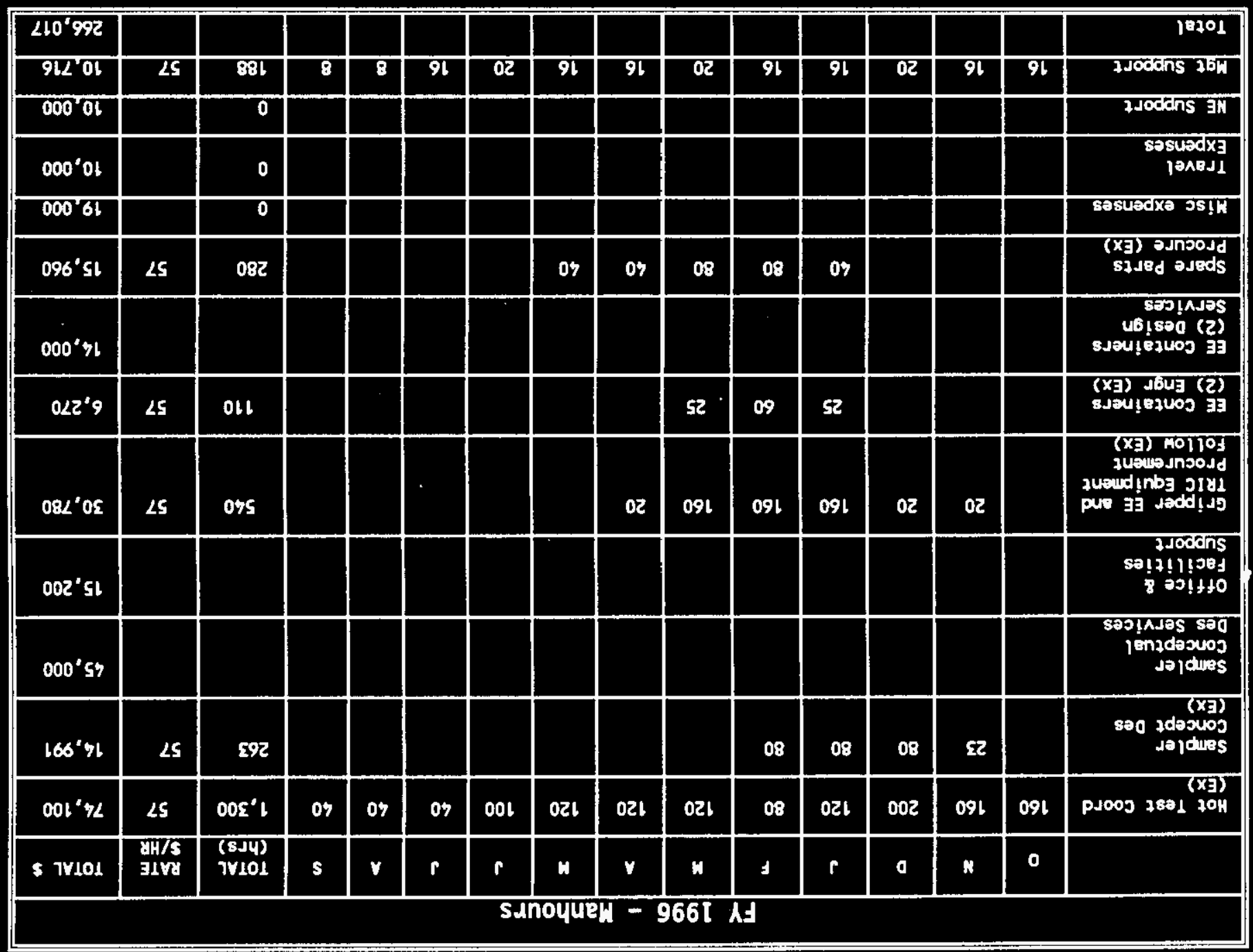

\section{- quaud ly}

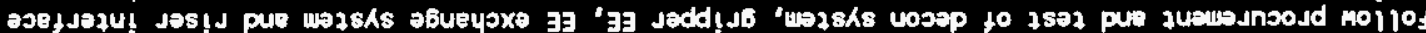

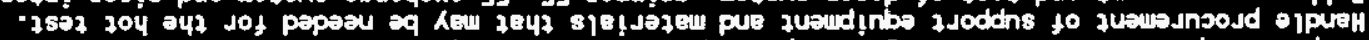

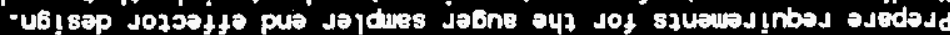

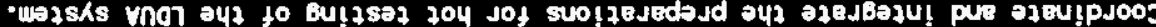




\subsection{EMERGENCY/SAFETY QUALITY SERVICES (D. J. Swaim, Mgr, 30000)}

\subsubsection{Characterization Project ESQ (J. M. Garcia, Mgr, 3E000)}

Characterization Emergency Safety/Quality engineering will provide quality assurance (QA) and Safety oversight of the Characterization sponsored field hot test work, including preparation of documentation packages needed for the ORR. Characterization ESQ will have lead responsibility for coordinating all QA and Safety activities.

\section{Characterization ESQ}

Scope of York: 1) Modify and update a quality assurance plan for the hot test preparation and implementation.

2) Review and approve the design and fabrication docunents, work plans, work instructions,

and test procedures and reports, as required.

3) Perform the necessary surveillance and inspection activities to assure conformance to the appropriate documents and procedures throughout fabrication and testing.

4) Perform desien verification activities to ensure that the as-built engineering docunentation reflects final system configuration.

5) Support "Operational Readiness Review" (ORR) and field operation of equipment.

6) Provide inclustrial safety review of plans and procedures for LDUA hot test in T-106.

7) Perform safety surveillance of cold and hot test preparations and operations.

\begin{tabular}{|c|c|c|c|c|c|c|c|c|c|c|c|c|c|c|c|}
\hline \multicolumn{16}{|c|}{ FY 1996 - Manhours } \\
\hline & 0 & V & D & J & $F$ & M & $\boldsymbol{A}$ & M & $J$ & $J$ & A & $\mathbf{s}$ & $\begin{array}{l}\text { TOTAL } \\
\text { (hrs) }\end{array}$ & $\begin{array}{l}\text { RATE } \\
\text { S/HR } \\
\end{array}$ & TOTAL $s$ \\
\hline $\begin{array}{l}\text { M. MeElroy } \\
\text { Design \& ORR Doc } \\
\text { Review, S\&I, Des. } \\
\text { Verif, oRR ô Sugeort }\end{array}$ & & & 20 & 20 & 20 & 20 & 20 & 20 & 40 & 40 & 30 & 20 & 250 & 59 & 14,750 \\
\hline $\begin{array}{l}\text { J. A. Harvey } \\
\text { Industrial Safety }\end{array}$ & & & & 8 & 8 & 8 & 4 & 24. & 28 & 8 & 4 & 8 & 100 & 59 & 5,900 \\
\hline Total & & & & & & & & & & & & & 0 & & 20,650 \\
\hline
\end{tabular}

\subsubsection{Tank Waste Remediation System Quality Assurance (J. Weber, 38200)}

Tank Waste Remediation System QA provides operational QA support to the tank farms operating groups. The T Farm Cognizant QA engineer will provide operational QA oversight of the hot test Work Package preparation and field work for the $T$ Farm.

\section{TWRS Quality Assurance}
Scope of Hork: 1) Identify tank farm specific od requirements for preparation of hot test planning documents.
2) Support revieu of $T$ Farm work packages for hot test preparation and implententation.
3) Review hot test plan draft.
4) Review plan
5) Provide field aC at tank farm during setup/takedown.

\begin{tabular}{|c|c|c|c|c|c|c|c|c|c|c|c|c|c|c|c|}
\hline \multicolumn{16}{|c|}{ FY 1996 - Manhours } \\
\hline & 0 & $\mathrm{~N}$ & D & J & $\mathbf{F}$ & M & $\boldsymbol{A}$ & H & $\mathbf{J}$ & 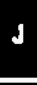 & $A$ & $\mathbf{s}$ & $\begin{array}{l}\text { TOTAL } \\
\text { (hrs) }\end{array}$ & $\begin{array}{l}\text { RATE } \\
\text { S/HR }\end{array}$ & TOTAL $s$ \\
\hline $\begin{array}{l}\text { J. F. Bores } \\
\text { Sipport LDUA Hot } \\
\text { Iest Inst }\end{array}$ & & & & & 10 & 10 & & 20 & 20 & & 20 & 30 & 110 & 59 & 6,490 \\
\hline Total & & & & & & & & & & & & & & & 6,490 \\
\hline
\end{tabular}


4.6 SAFETY (L. L. Reed, Mgr, 31000)

\subsubsection{TWRS Safety Integration (L. M. Calderon, Mgr, 31NO0)}

TPS will prepare an Electrical Hazards Class Determination for the LDUA system and will provide a Safety overview of the preparations for hot testing of the LDUA system.

\section{SAFETY}

Scope of Uork: 1) Prepare Electrical/Hazard Class Determination

\begin{tabular}{|l|l|l|l|l|l|l|l|l|l|l|l|l|l|l|l||}
\hline \multicolumn{10}{|c|}{ FY 1996 - Manhours } \\
\hline & 0 & N & D & J & F & N & A & M & J & J & A & S & $\begin{array}{l}\text { TOTAL } \\
\text { (hrs) }\end{array}$ & $\begin{array}{c}\text { RATE } \\
\text { S/HR }\end{array}$ & TOTAL S \\
\hline $\begin{array}{l}\text { R. Huckfeldt } \\
\text { Haz. Class } \\
\text { Determ. }\end{array}$ & & & 8 & & & & & & & & & & 8 & 61 & 488 \\
\hline Total & & & & & & & & & & & & & & & 488 \\
\hline
\end{tabular}

\subsection{SAFETY ANALYSIS AND NUCLEAR ENgINEERING (A. L. Ramble, Mgr, 8m000)}

\subsubsection{TWRS SAR Engineering (E. P. DiVincenzo, Mgr, 8H100)}

Safety Analysis and Nuclear Engineering will have the lead responsibility in preparing the required safety analys is document. Some work on the Hazards Operability Study (HAZOPS), Preliminary Hazards Analysis, and Preliminary Safety Equipment List was completed in prior years. These tasks will be completed together with a Fire Hazards Evaluation (FHE), Safety Equipment List (SEL), the Safety Analysis Document (SAD) and an Unreviewed Safety Question Evaluation.

\subsubsection{Consequence Analys is}

Consequence Analysis (D. S. Leach, 8M400) or another qualified organization will perform a consequence analysis of the LDUA operations in support of the SAD preparation. 
TWRS SAME Manpower Estimate By Major Task

A. Develop safety equipment 1ist (SEL) in support of the LDUA.

$\begin{array}{ll}\text { Scope of Work: } & \text { 1) } \\ \text { 2) } & \text { Pevel op Safety Equipment List (SEL) }\end{array}$

3) Functional Review

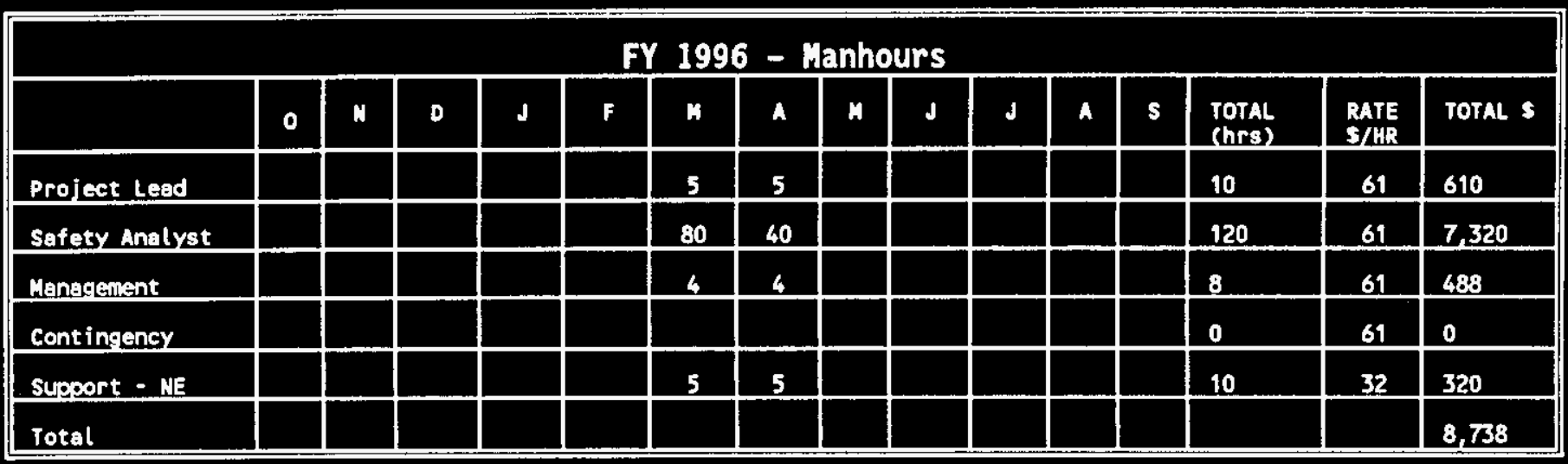

B. Develop safety documentation (SARR) in support of the LDUA.

$\begin{array}{lll}\text { Scope of York: } & \text { 1) } & \text { Hazard Class Determination } \\ \text { 2) } & \text { Hazard Ident if ication } \\ \text { 3) } & \text { Develop Accident Scenarios } \\ \text { 4) } & \text { Develop Consequence Analys is } \\ \text { 5) } & \text { Ident ify Controls } \\ \text { 6) } & \text { Perform Fire Protection Evaluat ion } \\ \text { 7) } & \text { Peer Review } \\ \text { 8) } & \text { Funct ional Review } \\ \text { 9) } & \text { SEAC Review } \\ \text { 10) } & \text { Testing support } \\ \text { 11) } & \text { Coordinate LANL Safety docunentation support }\end{array}$

\begin{tabular}{|c|c|c|c|c|c|c|c|c|c|c|c|c|c|c|c|}
\hline \multicolumn{16}{|c|}{ FY 1996 - Manhours } \\
\hline & 0 & N & D & $\checkmark$ & $\mathbf{F}$ & M & $\boldsymbol{A}$ & M & $\mathbf{d}$ & 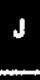 & $\boldsymbol{A}$ & $\mathbf{s}$ & $\begin{array}{l}\text { TOTAL } \\
\text { (hrs) }\end{array}$ & $\begin{array}{l}\text { RATE } \\
\text { SALR }\end{array}$ & TOTALs \\
\hline Project Lead & & 4 & 16 & 46 & 46 & 62 & 110 & & & & & & 284 & 61 & 17,326 \\
\hline $\begin{array}{l}\text { Safety } \\
\text { Analyst }\end{array}$ & & & 80 & 130 & 130 & 130 & 130 & & & & & & 600 & 61 & 36,600 \\
\hline $\begin{array}{l}\text { Consequence } \\
\text { Analysis }\end{array}$ & & & 160 & 160 & 160 & 80 & 80 & & & & & & 640 & 61 & 39,040 \\
\hline $\begin{array}{l}\text { Contractor } \\
\text { (FHA) }\end{array}$ & & & & $x$ & & & & & & & & & 0 & 61 & 30,000 \\
\hline Management & & 2. & 8 & 8 & 8 & 8 & 8 & & & & & & 42 & 61 & 2,562 \\
\hline $\begin{array}{l}\text { Editing/word } \\
\text { processing }\end{array}$ & & & & & 40 & & 40 & & & & & & 80 & 61 & 4,880 \\
\hline support - NE & & 10 & 10 & 10 & 10 & 10 & 10 & & & & & & 60 & 32 & 1,920 \\
\hline $\begin{array}{l}\text { Contract } \\
\text { Supoort - BoA }\end{array}$ & & & & & & & & & & & & & & & 100,000 \\
\hline Total & & & & & & & & & & & & & & & 232,326 \\
\hline
\end{tabular}




\section{USQ Evaluation}

Scose of Hork:
1) Isolate/Address USAs
2) Review/Connent USes
3) Finalize USas
4) Submit Responses to Usas for approval

\begin{tabular}{|c|c|c|c|c|c|c|c|c|c|c|c|c|c|c|c|}
\hline \multicolumn{16}{|c|}{ FY 1996 - Manhours } \\
\hline & 0 & $n$ & D & J & $\mathbf{F}$ & $M$ & $\boldsymbol{A}$ & M & J & 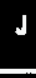 & $\mathbf{A}$ & $\mathbf{s}$ & $\begin{array}{l}\text { TOTAL } \\
\text { (hrs) }\end{array}$ & $\begin{array}{l}\text { RATE } \\
S / H R\end{array}$ & $\begin{array}{l}\text { TOTAL } \\
\mathbf{s}^{2}\end{array}$ \\
\hline Project Lead & & & & & & & 2 & & & & & & 2 & 61 & 122 \\
\hline Safety Analyst & & & & & & & 40 & & & & & & 40 & 61 & 2,440 \\
\hline Management & & & & & & & 4 & & & & & & 4 & 61 & 244 \\
\hline Contingency & & & & & & & 8 & & & & & & 8 & 61 & 488 \\
\hline Total & & & & & & & & & & & & & 0 & & 3,294 \\
\hline
\end{tabular}

\subsection{PROJECT SERVICES (B. G. Erlandson, Mgr, 01810)}

\subsubsection{Environmental Services (K. S. Tollefson, Lead)}

Environmental Services will prepare the NEPA/SEPA and RCRA documentation. Additionally, air permit applications will be prepared and processed through the EPA, Department of Ecology and the Department of Health for needed reviews and approvals. A necessary input for the air permit applications is data on the chemical and radiological character of the tank head space off gases. This characterization will be provided by historical data and laboratory analysis.

\section{Environmental Services}

Scope of Work: 1) Prepare MEPA menorandum

2) Prepare RCRA menorandum

3) Prepare Point of Contact (POC) Checklist

4) Prepare Air Permit applications and coordinate approval with DOH, EPA, and Ecology.

\begin{tabular}{|c|c|c|c|c|c|c|c|c|c|c|c|c|c|c|c|}
\hline \multicolumn{16}{|c|}{ FY 1996 - Manhours } \\
\hline & 0 & $n$ & 0 & $d$ & $\mathbf{F}$ & $\mathbf{M}$ & 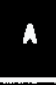 & $n$ & J & $J$ & $A$ & s & $\begin{array}{l}\text { TOTAL } \\
\text { (hrs) }\end{array}$ & $\begin{array}{l}\text { RATE } \\
\text { S/HR }\end{array}$ & TOTAL $\$$ \\
\hline MEPA DSI/SEPA & & & 40 & & & & & & & & & & 40 & 55 & 2,200 \\
\hline RCRA Memo & & & 5 & & & & & & & & & & 5 & 55 & 275 \\
\hline $\begin{array}{l}\text { Air Permits/ } \\
\text { Approval }\end{array}$ & & & 5 & 25 & 80 & 20 & 30 & 30 & 10 & & & & 200 & 55 & 11,000 \\
\hline $\begin{array}{l}\text { Poc Checkl ist/ } \\
\text { Permit plan }\end{array}$ & & & 40 & & & & & & & & & & 40 & 55 & 2,200 \\
\hline Total & & & & & & & & & & & & & & & 15,675 \\
\hline
\end{tabular}




\subsection{ENGINEERING TESTING AND TECHNOLOGY PROJECTS}

\subsubsection{Remote Systems/Sensor Applications (D. S. Dutt, Mgr, 8A800)}

The RSSA organization has had the lead responsibility for development of the LDUA under the sponsorship of DOE, EM-50. This group will provide consulting support during the ORR and subsequent setup and hot testing of the LOUA system at T Farm. Their costs, 1 isted below, are covered by the EM-30 budget.

Scope of Wark: 1) Prepare and test software control of Gripper end effector.

2) Prepare and test software control of interface for moisture detector end effector.

3) Provide moisture monitor I8E package integration.

4) Provide trained craft support for LoUA hot test.

5) Provide energency backup to the Characterization Project Design Authority during hot testing with R. Truitt.

\begin{tabular}{|c|c|c|c|c|c|c|c|c|c|c|c|c|c|c|c|}
\hline \multicolumn{16}{|c|}{ FY 1996 - Manhours } \\
\hline & 0 & $N$ & D & $J$ & $\mathbf{F}$ & $\mathbf{M}$ & $A$ & $r$ & $\mathbf{J}$ & J & A & $\mathbf{s}$ & $\begin{array}{l}\text { TOTAL } \\
\text { (hrs) }\end{array}$ & $\begin{array}{l}\text { RATE } \\
\text { S/HR }\end{array}$ & TOTAL $s$ \\
\hline $\begin{array}{l}\text { Provide Gripper EE } \\
\text { control }\end{array}$ & & & & & 24 & 32 & 32 & 36 & 16 & & & & 140 & 61 & 8,540 \\
\hline $\begin{array}{l}\text { Provide moisture } \\
\text { monitor control } \\
\text { interface }\end{array}$ & & & & & 32 & 80 & 4 & 24 & 56 & & & & 232 & 61 & 14,152 \\
\hline $\begin{array}{l}\text { ACES Certification } \\
\text { craft training, } \\
400 \text { Area crafts } \\
\end{array}$ & & & & & & & & & & 200 & & & 200 & 44 & 8,800 \\
\hline $\begin{array}{l}\text { ACEs Certification } \\
\text { backup, Design } \\
\text { Authority }\end{array}$ & & & & & & & & & & & 40 & & 40 & 61 & 2,440 \\
\hline $\begin{array}{l}\text { LDUA Setup at tank } \\
\text { farm (BU) } \\
400 \text { Area crafts }\end{array}$ & & & & & & & & & & & 200 & 260 & 460 & 44 & 20,240 \\
\hline Total & & & & & & & & & & & & & & & 54,172 \\
\hline
\end{tabular}

\subsection{OTHER SUPPORTING ORGANIZATIONS}

Other supporting organizations will work in two matrix teams.

1. The Plant Readiness Team (PRT) will plan the activities of the Plant Readiness Team to collect, and review all necessary documents to support the Hot Test mission and will certify their adequacy for presentation to the Operational Readiness Review Board. The PRT will be a cross-organization group, including West Tank Farm Transition Project staff, Quality Assurance, Safety and Characterization Project staff. 
Plant Readiness Team

Scope of York: 1) Prepare the Plan of Action for RL approval

Prepare the Plant Readiness Plan and Check Lost.

Review and certify completeness of certification packages.

Issue the Plant Readiness Final Report.

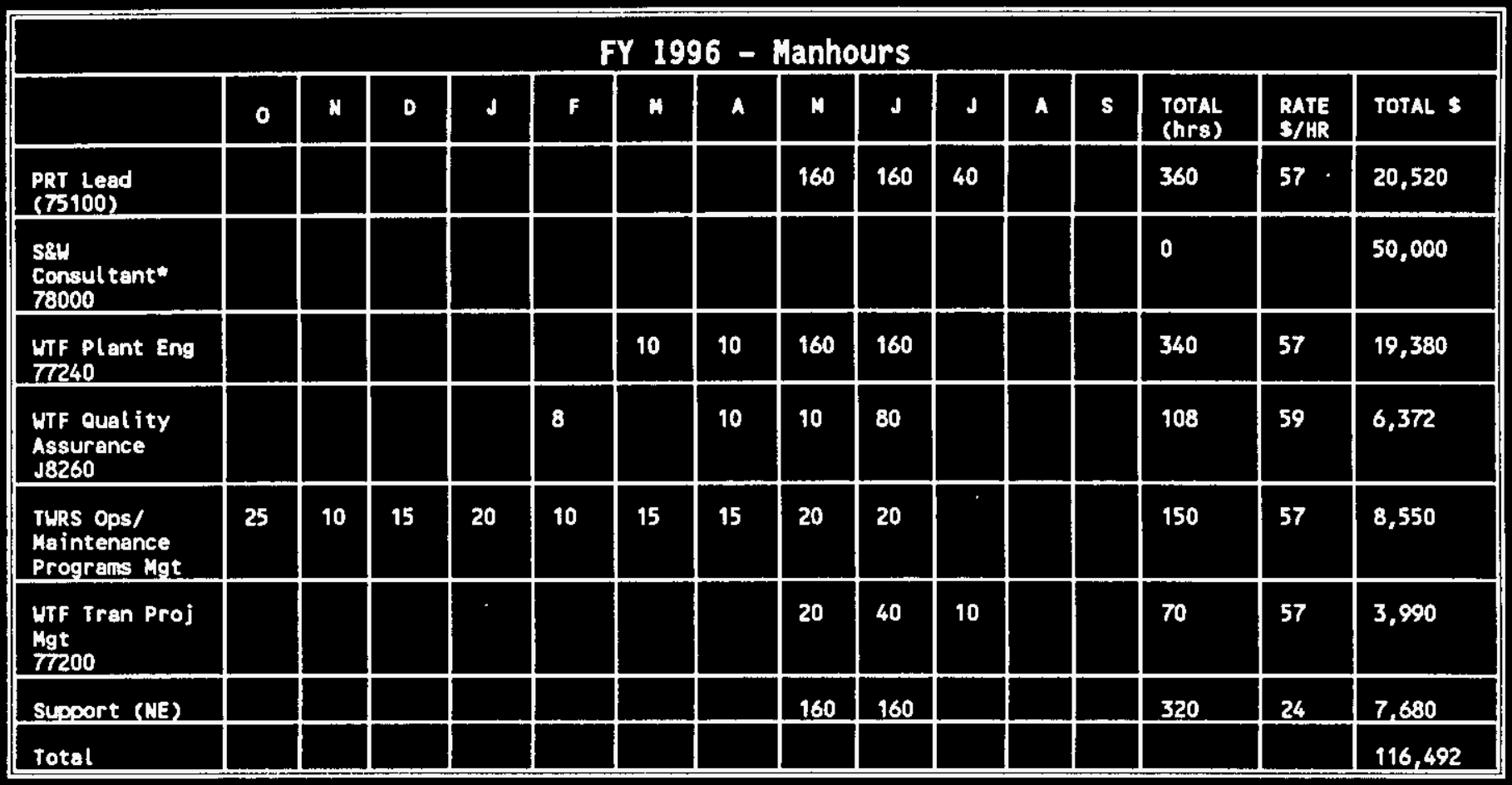

\section{Operational Readiness Review Team}

Scope of Uork) 1) Prepare the Readiness Review Implenentation Plan and Check List.
2) Perform Operational Readiness Review.

2) Perform Operational Readiness Revieu.

\begin{tabular}{|c|c|c|c|c|c|c|c|c|c|c|c|c|c|c|c|}
\hline \multicolumn{16}{|c|}{ FY 1996 - Manhours } \\
\hline & 0 & n & D & J & $\mathbf{F}$ & M & $\boldsymbol{A}$ & $\boldsymbol{n}$ & J & 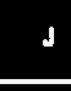 & $\boldsymbol{A}$ & s & $\begin{array}{l}\text { TOTAL } \\
\text { (hrs) }\end{array}$ & $\begin{array}{l}\text { RATE } \\
\text { S/HR } \\
\end{array}$ & TOTAL $\$$ \\
\hline $\begin{array}{l}\text { J. Rathbun } \\
\text { ORR Board } \\
\text { Chair }\end{array}$ & & & & & & & & 40 & 40 & 110 & 40 & & 230 & 57 & 13,110 \\
\hline $\begin{array}{l}\text { ORR } \\
\text { Coordinator }\end{array}$ & & & & & & & & & 20 & 120 & & & 140 & 57 & 7,980 \\
\hline $\begin{array}{l}\text { ORR } \\
\text { Reviewers }\end{array}$ & & & & & & & & & & 600 & & & 600 & 57 & 34,200 \\
\hline Support (NE) & & & & & & & & & & 80 & & & 80 & 24 & 1,920 \\
\hline Total & & & & & & & & & & & & & 0 & & 57,210 \\
\hline
\end{tabular}


Other Support Services

Scope of York: 1) Riggers-move and transport equipment-400 Area to 200 Area Truck drivers to move equipment to $200 \mathrm{~W} T$ Farm.

Prepare RSR for moving contaninated LDUA from $T$ Farm to HR shop.

Riggers - move and transport equipment, $T$ farm to storage in 200 Area.

Truck drivers to nove equipment, T Farm to storage in 200 Ares.

\begin{tabular}{|c|c|c|c|c|c|c|c|c|c|c|c|c|c|c|c|}
\hline \multicolumn{16}{|c|}{ FY 1996 - Manhours } \\
\hline & 0 & N & D & 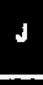 & $\mathbf{F}$ & $M$ & $A$ & $n$ & 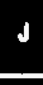 & $d$ & $\Lambda$ & s & $\begin{array}{l}\text { TOTAL } \\
\text { (hrs) }\end{array}$ & $\begin{array}{l}\text { RATE } \\
\text { S/HR } \\
\end{array}$ & TOTAL $\$$ \\
\hline $\begin{array}{l}\text { Rigging Crew } \\
\text { (BU) (52200) }\end{array}$ & & & & & & & & & & & 160 & 200 & 360 & 44 & 15,840 \\
\hline $\begin{array}{l}\text { Truek driver } \\
\text { (BU) }(52300)\end{array}$ & & & & & & & & & & & 16 & 24 & 40 & 44 & 1,760 \\
\hline $\begin{array}{l}\text { HPT support (BU) } \\
\text { (3E110) }\end{array}$ & & & & & & 40 & & & & & 40 & 208 & 288 & 46 & 13,248 \\
\hline $\begin{array}{l}\text { RSR Prep (Ex) } \\
84300\end{array}$ & & & & & & & & & & & 40 & & 40 & 61 & 2,440 \\
\hline $\begin{array}{l}\text { Industrial } \\
\text { Hygiene support }\end{array}$ & & & & & 4 & & & & & & 8 & & 12 & 48 & 576 \\
\hline Totel & & & & & & & & & & & & & & & 33,864 \\
\hline
\end{tabular}

\subsection{ASSUHPTIONS AND CONDITIONS}

\subsubsection{Assumptions}

This Engineering Task Plan is based upon the following assumptions:

1. The LDUA System will not be transferred to the Characterization Program for production operation until successful completion of the cold Qualification Test (Acceptance Test Procedure, ATP) in the 400 Area Cold Test Facility, and the hot Operability Test Procedure (OTP) at a designated waste tank.

2. Certain documentation is required to support the Operational Readiness Review to authorize the access to the waste tank for the OTP (Hot Test). This documentation will be prepared in similar format and level of content to documents used by the Characterization Operations organization for operation, and staff training so that it may be readily adaptable to the operating organization needs following the Acceptance Test and actual turnover to Operations. Preparation of integrated maintenance manuals will not be implemented by the operating organization until after the OTP.

3. The OTP (Hot Test) will be conducted in tank T-106 in the T Farm. As a backup, tank T-109 will be the alternate test location.

4. The OTP (Hot Test) is not expected to require the use of a tank exhauster. However, as a contingency and to support post turnover use, permitting activity is required which will provide Washington State air permits. 
5. The Characterization Organization has portable electrical generators available to support it's other work. The budget and schedule for the LDUA OTP assumes the availability of this equipment during the June 1996 ATP (Cold Qualification Test) and the September 1996 OTP (Hot Test).

\subsubsection{Conditions}

1. The Characterization Project (Characterization Equipment Engineering) has accepted the lead role in supporting this hot Acceptance Test activity and will provide a Cognizant Engineer, Cognizant Engineer backup, a Person In Charge (PIC) for field operations, and needed nuclear power operators for system operation. These personnel will be made available to be trained in the Cold Test Facility in the 400 Area (April-June) and for subsequent field operations in August/September 1996 in support of the current schedule.

2. The Remote Systems/Sensor Applications organization representing the DOE Office of Technology Development, will provide engineering and needed support services to receive the equipment in the 400 Area Cold Test Facility (CTF), perform needed system integration and development, and conduct the cold Qualification Test (ATP) of the system in the Cold Test Facility.

3. TWRS Engineering will be responsible for defining, coordinating and managing the preparations for the hot OTP in August/September 1996.

4. Vendor drawings for the system components are being provided as Hanford H-6 series drawings.

\subsubsection{Hot Testing Support and Equipment Maintenance}

During the hot testing phase, experienced engineering and craft support will be required.

Remote systems/sensor applications (RS/SA) Design Authority will serve as backup for the Characterization Project's appointed Design Authority during the hot testing.

RS/SA will also arrange for crafts personnel who have worked on the equipment set-up, operation, and maintenance at the CTF to be available to perform similar tasks during hot testing. RS/SA will assist in arranging for its staff and craft support to receive ACES certification by July 1996 in preparation for the first hot test.

\subsubsection{Turnover}

Following successful completion of the hot OTP, custody and operational responsibility of the LDUA system and support equipment will be retained by the Characterization Equipment Engineering (CEE) group for further in-tank testing missions during FY 1997 if deemed necessary. 
Following this extended testing phase, the system will be transferred to Characterization Operations for beneficial use. At that time, the responsibility for Design Authority and Cog Engineering Support will be assigned to the appropriate Characterization organization.

Maintenance documentation for the subsystems will be provided by the suppliers. CEE will be responsible for consolidating these data into an integrated maintenance document and the training of Characterization Project maintenance personnel. A draft Acceptance for Beneficial Use (ABU) checklist is provided in Appendix $D$.

\subsection{SCHEDULE MILESTONES}

The following are major milestones based on the LDUA Program integrated schedule dated December 18, 1995 and may vary on subsequent schedule updates.

\begin{tabular}{|c|c|c|c|}
\hline $\begin{array}{l}\text { Activity } \\
\text { No. }\end{array}$ & $\begin{array}{l}\text { Responsible } \\
\text { Mgr. }\end{array}$ & $\begin{array}{l}\text { Completion } \\
\text { Date }\end{array}$ & Description \\
\hline Ł3821 & SJ Dechter & $01 / 19 / 96$ & DOE/RL approve ORR Plan of Action \\
\hline$\llcorner 3824$ & SJ Dechter & $02 / 16 / 96$ & $\begin{array}{l}\text { ORR Implementation } P 1 \text { an and } \\
\text { Checklist to DOE/RL for information }\end{array}$ \\
\hline L3851 & DS Dutt & $02 / 01 / 96$ & Receive SPAR draft 0\&M manuals. \\
\hline L3861a & DC Langlois & $04 / 10 / 96$ & $\begin{array}{l}\text { Tank site survey and riser gauging } \\
\text { complete }\end{array}$ \\
\hline L3832 & BG Erlandson & $07 / 14 / 96$ & Receive approved air permits \\
\hline L3845 & EP DiVincenzo & $04 / 28 / 96$ & Safety Assessment complete \\
\hline L3847 & EP DiVincenzo & $04 / 30 / 96$ & USQ evaluation complete \\
\hline L3852 & RE Bauer & $06 / 27 / 96$ & $\begin{array}{l}\text { LDUA operator training and } \\
\text { qual ification complete }\end{array}$ \\
\hline L3861b & RE Bauer & $05 / 29 / 96$ & Complete tank selection confirmation \\
\hline L3826 & JG Burton & $06 / 26 / 96$ & $\begin{array}{l}\text { Plant Readiness Team final report } \\
\text { complete/transmitted to WHC ORR Team }\end{array}$ \\
\hline$L 333$ & DS Dutt & $07 / 09 / 96$ & $\begin{array}{l}\text { LDUA system cold qualification } \\
\text { testing completed }\end{array}$ \\
\hline $\mathbf{L} 3827$ & LL Reed & $08 / 13 / 96$ & $\begin{array}{l}\text { WHC Operational Readiness Review } \\
\text { final report to RL }\end{array}$ \\
\hline 13827 & SJ Dechter & $08 / 20 / 96$ & RL ORR complete \\
\hline L3864 & DC Langlois & $09 / 03 / 96$ & $\begin{array}{l}\text { LDUA system installation at tank } \\
\text { farm complete }\end{array}$ \\
\hline L3866 & DC Langlois & $09 / 20 / 96$ & Hot testing complete \\
\hline L3867 & DC Langlois & $09 / 30 / 96$ & $\begin{array}{l}\text { LDUA system removed from tank farm } \\
\text { to regulated storage and maintenance } \\
\text { area }\end{array}$ \\
\hline
\end{tabular}




\subsection{COST ESTIMATE SUMMARY}

6.1 EXPENSE COST ESTIMATE SUMAARY (AII amounts are fully burdened) Org Code Manager Organization

Amount (\$)

$\begin{array}{ll}75000 & \text { L. F. Ermold } \\ 75100 & \text { J. G. Burton } \\ 75110 & \text { J. A. Kimbrough } \\ 75120 & \text { B. J. Shoemake } \\ 75140 & \text { D. C. Langlois } \\ 75200 & \text { R. E. Raymond } \\ 75240 & \text { R. E. Bauer } \\ 75250 & \text { C. E. Hanson }\end{array}$

Characterization Project

Characterization Operations

Production Control and Maint. 14,820

Equip. Programs

13,570

Ops/Remote-Surv/Eq.Dec.

143,860

Characterization Equipment Engineering

Monitoring Development

Equipment Devel opment

233,604

Sub Total

28,500

$\$ \longdiv { 4 3 4 , 3 5 4 }$

77000

J. H. Wicks, Jr.

Tank Farm Transition Project

77200

D. P. Reber

Nest Tank Farms Transition Project

77240

S. H. Rifaey

Plant Engineering

5,472

77500

C. J. Geier

Environmental Cleanup/Compliance Project

77530

R. D. Gustavson

Environmental Engineering

4,560

77700

L. E. Simmons, Jr.

77710

P. Jennings

Shift Ops Training

53,440

Sub Total

$\$ 63,472$

74000

A. M. Unek

TWRS Engineering

74200

E. J. Lipke

Safety Engineering

74210

G. T. Dukelow

Safety Engineering Program

10,384

74400

J. D. Thomson

TWRS Technical Integration

74420

R. K. Brown

Tank Systems Integration

266,017

Sub Total

$\$ \longdiv { 2 7 6 , 4 0 0 }$ 
WHC-SD-WM-ETP-176 Rev. 0

Org Code Manager

\begin{tabular}{ll}
30000 & D. J. Swain \\
36000 & J. M. Garcia \\
38000 & J. H. Roberts \\
38260 & J. Weber \\
31000 & L. L. Reed \\
31010 & L. M. Calderone \\
84000 & A. L. Ramble \\
$8 M 100$ & EP DiVincenzo \\
01800 & W. T. Dixon \\
01810 & B. G. Erlandson \\
$8 A 000$ & L. C. Brown \\
$8 A 800$ & D. S. Dutt \\
MisC & \\
MisC & \\
MisC & \\
\hline
\end{tabular}

Organization

Amount

(\$)

Emergency/Safety/Quality Services

Characterization ESQ

20,650

TWRS Quality Assurance

Quality Assurance

6,490

Safety

Transition Project Safety

488

Safety Analysis and Nuclear Engineering

TWRS SAR Engineering

244,358

Environmental Services

Project Services

15,675

Engineering Testing/Technology Projects

Remote System/Sensor Application 54,172

Plant Readiness Team

116,492

Ops. Readiness Review Board

57,210

Other Support Services

33,864

Sub Total

$\$ \longdiv { 5 4 9 , 3 9 9 }$

$\$ 1,323,525$ 


\subsection{CENRTC FUNDED EQUIPMENT AND MATERIALS COST ESTIMATE SUNMARY}

The following hardware will be acquired with FY 1996 CENRTC funding:

1. LDUA replacement power \& control equipment

$\$ 260,000$

2. Moisture Detection End Effector

94,500

3. Overview Video Camera System duplicate

77,000

4. End Effector Storage \& Handling Containers

35,000

5. LDUA spare parts procurement

130,000

6. LDUA transportation costs to Hanford Site

55,000

7. Portable power distribution cable assemblies

10,000

8. Field power unit interface equipment

15,000

9. LDUA Operations Overview Video System

10,000

10. Replacement EM-50 test equipment

30,000

11. Miscellaneous equipment expenses

$\underline{20,000}$

CENRTC Total Cost Estimate

$\$ 736,500$

Total Estimated Expense/CENRTC Cost (Rounded)

$\$ \longdiv { 2 , 0 6 0 , 0 0 0 }$

\subsection{QUALITY ASSURANCE}

Quality Assurance/Control activities for all LDUA Hot Test support equipment, material and services shall be executed in accordance with Tank Waste Remediation System Characterization Project Quality Policies, WHC-SD-WM-QAPP-025, Rev. 1, and WHC-SD-WM-QAPP-021 Rev. 0. The QAPP shall be used to develop verification criteria for design documents, i.e., drawings, specifications, test procedures, and to define quality assurance interfaces.

\subsection{SAFETY}

\subsection{FIRE SAFETY CRITERIA}

All equipment and systems designed for the LDUA Hot Test shall meet the following criteria if within or part of the tank flammable gas envelope of watch list tanks or USQ tanks when installed on the tank riser:

8.1.1 Designed to meet NFPA Class 1, Division 1, Group B or

8.1.2 Designed to meet NFPA Class 1, Division 2, Group B. 


\subsection{INDUSTRIAL SAFETY}

Equipment and system design shall reflect requirements for personnel safety when handling system components and the assembled system. Industrial safety reviews shall be in accordance with Safety Manual, WHC-CM-1-10 and Industrial Safety Manual Safety Standards, WHC-CM-4-3.

\subsection{SYSTENS ENGINEERING}

The LDUA system provides a means to support the TWRS Function and Requirement 4.2, Remediate Tank Waste, 4.2.1, Manage Tank Waste. Reich provides an analys is of the TWRS Function and Requirement 4.2.1 and the applications of the LDUA to meet the TWRS mission. Kiebel (1994) and Pardini (1995) provide LDUA system functions and requirements to support TWRS Function and Requirements 4.2.1.

\subsection{REFERENCES}

Bhatia, P. K., 1994, Tank Selection for Light Duty Utility Arm System Hot Testing in a Single-Shell Tank, WHC-SD-WM-ES-328, Rev. 0, Westinghouse Hanford Company, Richland, Washington.

Kiebel, G. R., 1994, Functions and Requirements for the Light Duty Utility Arm Integrated System, WHC-SD-TD-FRD-003, Rev. 0, Westinghouse Hanford Company, Richland, Washington.

Kiebel, G. R., 1995, Light Duty Utility Arm Baseline System Description, WHC-SD-TD-ER-005, Rev. C, Westinghouse Hanford Company, Richland, Washington.

Malhan, R., 1994, Quality Assurance Program Plan Light Duty Utility Arm (LDUA), WHC-SD-WM-QAPP-021, Rev. 0, Westinghouse Hanford Company, Richland, Washington.

NFPA/NEC, National Fire Protection Association, National Electrical Code 70.

Pardini, A. F, 1995, Design Criteria For The Light Duty Utility Arm System End Effectors, WHC-SD-TD-CR-001, Rev. 0, Westinghouse Hanford Company, Richland, Washington.

Reick, R. H., 1994, TWRS LDUA Utilization Study Report, WHC-SD-WM-ER-343, Rev 0 , Westinghouse Hanford Company, Richland, Washington.

Sparks, J. S., 1995, Tank Waste Remediation System Characterization Project Quality Policies, WHC-SD-WM-QAPP-025, Rev 0, Westinghouse Hanford Company, Richland, Washington. 
WHC-SD-WM-ETP-176 Rev. 0

This page intentionally left blank. 
WHC-SD-WM-ETP-176 Rev. 0

APPENOIX A

Letter, H. D. Harmon (WHC) to R. L. Gilchrist (WHC)

A-1 
WHC-SD-WM-ETP-176 Rev. 0

This page intentionally left blank.

A-2 
From: Tank Waste Remediation System

Phone: $3-4725$ R2-52

Date: Harch 13, 1992

Subject: LIGHT OUTY ARM/MANIPULATOR

To: R. L. Gilchrist $\quad$ L5-63

cc: J. L. Deichman

J. M. Henderson

W. C. Miller

D. J. Newl and

M. A. Payne

J. G. Propson

R. E. Raymond

J. H. Roecker

R. K. Helty

J. A. Yount

HOH/RER:LB/File

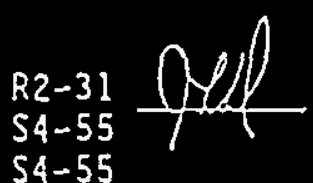

$54-55$

$54-55$; 92 ?

$\mathrm{R} 2-50$

R2-18

R1-80 REwEYGF:

S4-55 $12 x+20$

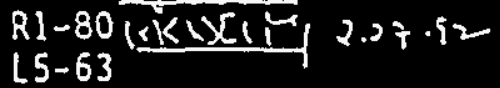

Since December 1991, Tank Waste Remediation System (THR)

staff members R. E. Raymond and R. K. Helty have been working closely with your organization in the development of a light duty arm/manipulator. This arm would be developed for use in Hanford underground storage tank (UST) characterization and retrieval activities. Of interest to THR are the following primary functions of this arm:

- Characterization of tank wastes

- Visual inspection of equipment

- Retrieval of wastes

- Placement of equipment

- Tank integrity evaluation

- Tank mapping

- Decontamination

- Remediation

- Interim stabilization

- Investigation of causes of tank leaks

Isolation/interim stabilization are ongoing activities that could employ several of the above functions, especially placement, visual inspection, and decontamination. Many of these functions could also be useful in the evaluation and remediation of priority I safety concerns. 
R. L. Gilchrist

Page 2

Narch 13, 1992

Installation of the arm will be supported by TWR, but it is expected that development of the manipulator will be funded by Technology Programs. To be most useful, deployment of the arm should occur within the next 18 months. The design of the arm will require very careful attention to safety factors involved with operations in and around Hanford USTs. Future uses of this arm will evolve as experience is gained through application of the arm in the tank farms. The best approach is to focus on a narrow set of applications (such as visual inspection) and build a prototype to be tested in one or more SSTs. Successful use of this prototype will then set the course for other applications.

The THR representative for development of the light duty arm is R. E. Raymond (or R. X. Kelty, Mr. Raymond's deputy for this activity), and future communication should be directed to them.

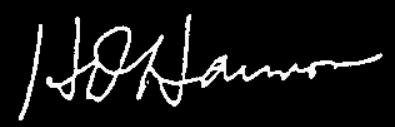

H. D. Harmon, Vice President

Tank Waste Remediation System

bjb 
WHC-SD-WM-ETP-176 Rev. 0

\section{APPENDIX B}

Letter, J. E. Kinzer (RL) to C. Frank (HQ)

B-1 
WHC-SD-WM-ETP-176 Rev. 0

This page intentionally left blank. 


\author{
- DAiE: April 12, 1995 \\ REPLY 10 \\ ATry of: RTI:STB 95-RTI-030 \\ SUBJET: DOE-FiL PLANHED UTILIZATION OF THE LIGHT DUTY UTILITY ARH (LOUA) \\ ro: Or. Clyda Frank, Deputy Assistant Secretary \\ for Technology Development, EM-50, HQ \\ This memorandum was prepared per the request of Dr. L Yarbrough, during his \\ recent visit to Hanford. The purpose of the memorandum is to formally \\ to the LDUA System, and it's planned \\ understand the data provided will uned utflization at the Hanford site. We \\ making regarding the relativa prlorities for to assist $\mathrm{HQ}$ in decision \\ Hanford, INEL and ORNL sites. \\ In Harch 1992, a letter was sent to Mr. Roger G1lchrist, the former \\ Underground Storaga Tank Integrated Demonstration (UST-ID) Program \\ Remediation organization in working interest of Hanford Sita Tank Waste \\ demonstrate this. system. This \\ LDUA System technology development ast was the impetus for initiating the \\ having such technology developed activities. Our fundamental interest in \\ is unchanged.
}

We have provided co-funding from the Tank Wasta Remediation System (TWRS, EH-30) budget since fisca) year (FY) 1993 to support this activity in cooperativa arrangement with the UST-ID and now the Tanks Focus Aras. outyear fundling proflies to support documents wera. submitted which identify organization is very concerned contract and has requested that the the cost escalation of the Spar a firm fixed price basis.

The successful negotiation of this continued plans to procura a system contract change is criticai to our growth coupled with severie cuts to for the Hanford tanks. This cost forced us to reprlorlelze our toct the Tank Wasto Operations budgets have operations. Ho are currently working is to ensure cont Inued safe obtain additional co-funding of the with the Characterization Program to continued participation depends upon LUA activities undar TWRS. Our 
FY 1996 to offset cost growth and budget cuts.

We continue to have strong neads associated with tank waste remediation, that wera presented to Dr. Yarbrough, of your staff, by Hr. John Propson of West Inghouse Hanford Company at your recent ravisy meeting on Harch 28, 1995. Although the deployment of the LDUA System is not specificaliy tied to individual Hanford Foderal Facllity Agresment and Consent Order (TriParty Agreament) milestones, it is considered to be an important tool in the overall mission planning to support regulatory drivers in the TPA.

The Characterization Program is currently evaluating the application of LDUA System technologies as part of the response to the Defense Nuciear Faclitty Safoty Board's finding 93-5. "Hanford Hasta Tanks Characterization Studies."

In FY 1994 an evaluation was conducted comparing the LDUA System to the THRS systems englneering functlonal hierachy. This evaluation is documented in an enginearing study report, "THRS LDUA Utilization study Report," WHC-SO-WH-ER-343, which was provided to your review team. This study compared the capablitities of the LDUA System to the TWRS mission planning and the positive conclustons formed the basis for continuing funding support of the LOUA under the Tank Haste Operations organization during FY 1995.

The results of this study showed that thera were many potantial applications for this technology that would support our cleanup mission. Our intentions are to focus nn a narrow set of applications for tho intiai deployment. However, we fully anticipats that when the system becomes avallable for operational usa, many new applications will ba identifled.

To summarlze, the need and interest in the LDUA System are still strong comittments for the DOE-RL Operations Office. We are however dealing with severe budget restrictions which are impacting our funding related to this activity. He are currently working with several programs within TWRS to determine if a sultable co-funding arrangement between Tank Wasta Operations and Cheracterization can be arranged to continue funding for this important work. TWRS is relying on the cont inved support of the Office of Technology Development (EH-50) to develop the system technology and to support us in successfully demonstrating this system in Hanford tanks. He have established a strong teaming relationship with the LDUA System development team and look farward to a continued strong partnership.<smiles>CCCOc1ccc(Oc2ccccc2)cc1</smiles>

Ce:

R. Ross8114, AMT, K8-50

D. Trader, ICC, KB-50 


\section{WHC-SD-WM-ETP-176 Rev. 0}

Or. Clyde Frank

95-RTI-030

$-3-$

D. Bowser, CHD, 57-54

Y. Krzesinskl, RTI, $57-53$

Or. L. Yarbrough, EM-54

D. Galser, EH-52

C. Mims, DOE-OR, IRC

J. Mocknick, EM-36 
WHC-SD-WM-ETP-176 Rev. 0

This page intentionally left blank.

B-6 
WHC-SD-WM-ETP-176 Rev. 0

APPENDIX C

MEMORANDUM

of

UNDERSTANDING

C-1 
WHC-SD-WM-ETP-176 Rev. 0

This page intentionally left blank. 
From: $\quad$ Remote System and Sensor Applications

Phone: $\quad 376-8695$ N1-21

Date: November 3, 1995

Subject: LIGHT DUTY UTILITY ARM SYSTEM - MEMORANDUM OF UNDERSTANDING

WHC9510.WP5

To:

W. C. Miller

$\begin{array}{ll}\text { cc: R. E. Bauer } & L 6-37 \\ \text { K. L. Bennett } & N 1-21 \\ \text { J. D. Berger } & L 0-18 \\ \text { R. K. Brown } & H 5-68 \\ \text { B. A. Carteret } & N 1-21 \\ \text { R. B. Conrad } & H 5-09 \\ \text { G. T. Dukelow } & 57-15 \\ \text { D. S. Dutt } & N 1-21 \\ \text { V. Fitzpatrick } & \text { K8-50 }\end{array}$

S4-55

P. H. Gibbons

G. R. Kiebel

J. H. Lee

R. E. Raymond

T. J. Samuel

G. H. Smith

P. A. Titzler

LDUA File/LB 1.1.6
H5-6I

N1-21

K9-91

$57+12$

N1-21

N1-21

H5-68

N1-21

This Memorandum of Understanding (MOU) documents the agreement between EM-50, Technology Development (TD) and EM-30, Tank Waste Remediation Systems (TWRS) regarding the Light Duty Utility Arm (LDUA) System. This MOU describes the close teaming arrangement that EM-30 and EM-50 have agreed upon for supply of each of the major items of equipment and support services that are necessary for the first Hanford field deployed LDUA System.

EM-50 has the responsibility to produce an LDUA System design that is in a 1 respects field deployable, (this includes appropriate design/fabrication reviews/approvals by WHC Quality Assurance and Safety organizations), and to qualify this system to be approved for hot deployment by means of an all-up system test. Accordingly, field grade subsystems have been produced for the qualification test; however, continued use of the EM-50 LDUA System in the Cold Test Facility (CTF) will not require field grade equipment. Some ancillary equipment will, therefore, be transferred to EM-30 to become part of the first Hanford field deployed LOUA System. In some cases (as described below), EM-30 will reimburse EM-50 with lab grade equipment in exchange for field grade equipment; in other cases EM-50 will use prototype equipment remaining from the development effort; and in still other cases, EM-50 will provide replacement equipment (generally where there is a need or opportunity for further development).

EM-30 will be responsible for all subsequent LOUA field systems as well as spares that are required to support them, including spares for the first field deployed LDUA System. EM-30 would also be responsible for providing the equipment or funding necessary to upgrade the EM-50 LDUA System in the CTF to be a more exact representation of the field system for training purposes, should that become necessary or desirable.

EM-50 will be responsible for providing all LDUA System procurement Quality Assurance and Safety support necessary to assist the equipment suppliers in the design and fabrication of the LDUA System. . EM-30 will be responsible for all Qual ity Assurance and Safety support necessary to obtain approvals for deployment of the LDUA System at the Hanford Site. EM-30 will be responsible for providing all Hanford Site approved operating, maintenance and training procedures. 
EM-30/50 Memorandum of Understanding November 3,1995

Page 2 of 6

EM-50 will be responsible for providing a complete Engineering Data Package containing all information necessary for EM-30 to operate and maintain the LDUA system. The Engineering Data Package shall include, but will not be limited to User's Manuals, Maintenance Manuals, Operating Specifications, Quality Assurance audit reports and Acceptance Test Reports.

The following table lists the major items of equipment for the first LDUA field system and describes the responsibility of EM-50 and EM-30 for each item. clarifying reference information is provided in the form of end notes.

Concurrence:
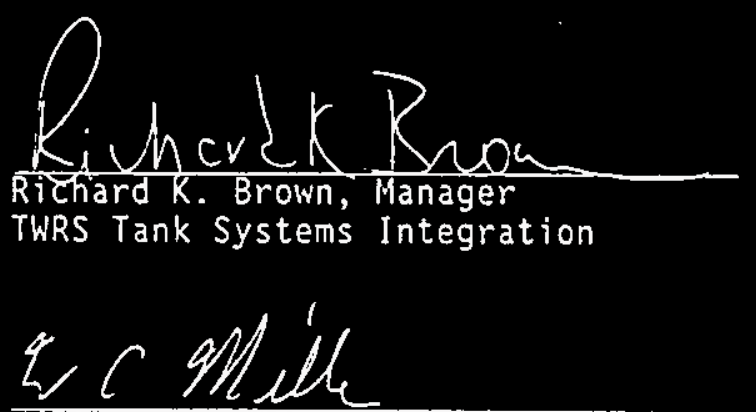

William C. Miller, Manager

TWRS Design Basis Integration
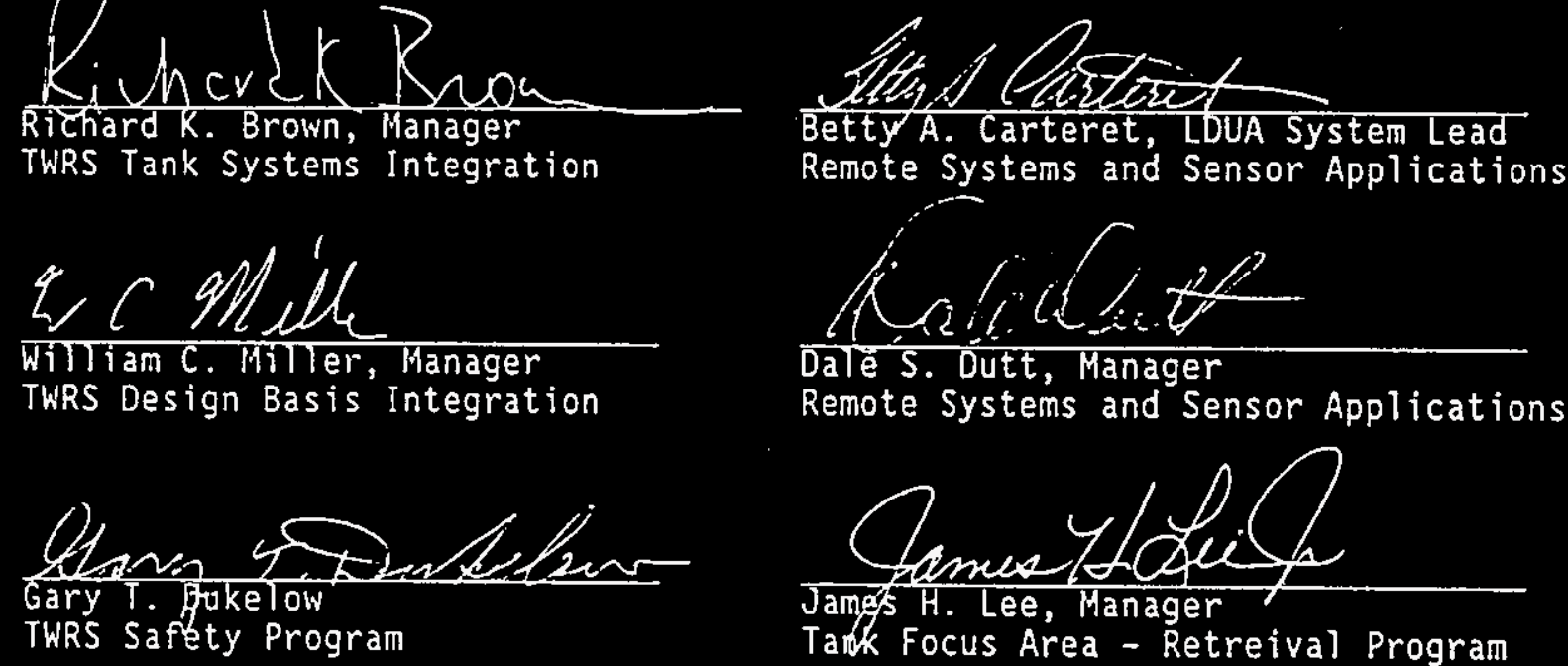

Dalé S. Dutt, Manager

Remote Systems and Sensor Applications
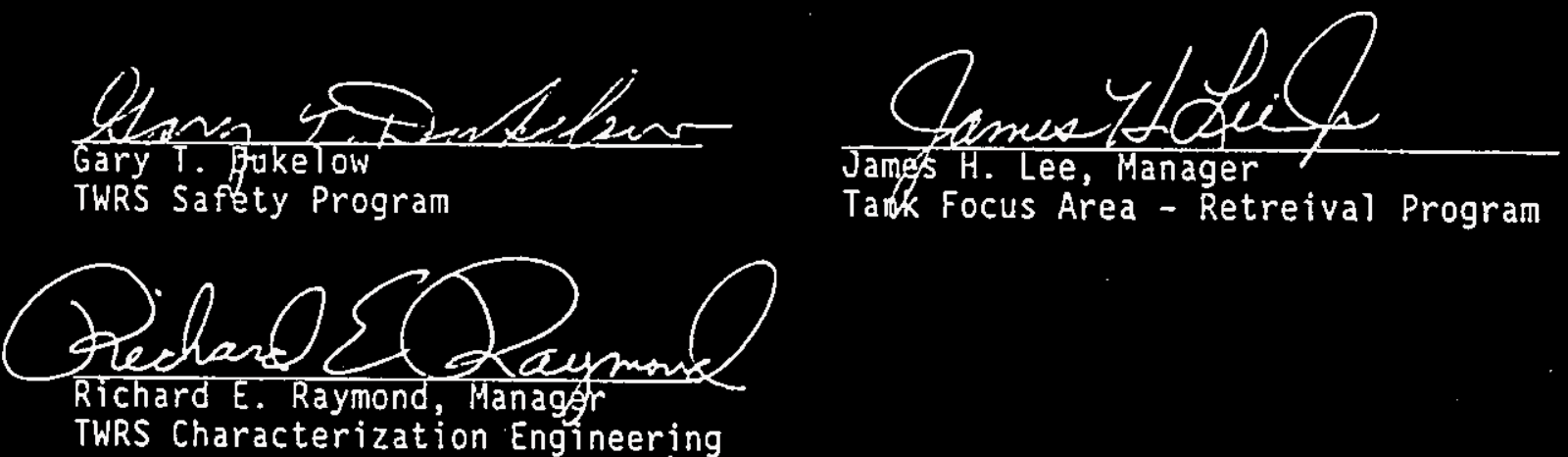

$$
11 / 29 / 95
$$




\begin{tabular}{|c|c|c|c|}
\hline \multicolumn{4}{|c|}{ EQUIPHEHT SUPPLY RESPOHSIBILITY FOR FIRST LDUA FIELD SYSTEH } \\
\hline System \# & Equipment & EM-50 & EM-30 \\
\hline 2000 & \multicolumn{3}{|l|}{ ARM AND DEPLOYMENT SYSTEM 1} \\
\hline $\begin{array}{l}2100 \\
2200 \\
2300 \\
2400 \\
\end{array}$ & $\begin{array}{l}\text { Mobile Deployment System }{ }^{2} \\
\text { Vertical Positioning Mast } \\
\text { Light Duty Utility Arm } \\
\text { Control System }\end{array}$ & $\begin{array}{l}\text { Provide baseline } \\
\text { design of system }\end{array}$ & $\begin{array}{l}\text { Procure unit under firm } \\
\text { fixed price contract } \\
\text { (FY94-95 C.R. funding) }\end{array}$ \\
\hline 3000 & \multicolumn{3}{|c|}{ TANK RISER INTERFACE AND CONFINEMENT (TRIC) } \\
\hline 3520 & Radiation Monitors 4 & $\begin{array}{l}\text { Design (FY95-96) } \\
\text { Procure (FY96) }\end{array}$ & \\
\hline 3700 & 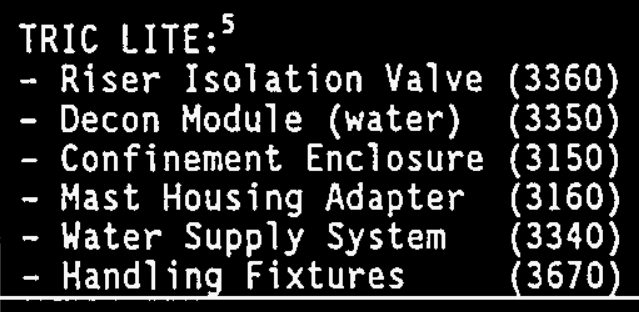 & & $\begin{array}{l}\text { Design (FY95-96) } \\
\text { Procure (FY95-96) } \\
\text { (FY95 C.R. funding) }\end{array}$ \\
\hline 3660 & $\begin{array}{l}\text { End Effector Exchange System } \\
\text { (Manual) }\end{array}$ & & $\begin{array}{l}\text { Design (FY95-96) } \\
\text { Procure (FY95-96) } \\
\text { (FY95 C.R. funding) }\end{array}$ \\
\hline 4000 & \multicolumn{3}{|l|}{ OPERATIONS CONTROL CENTER } \\
\hline 4100 & $\begin{array}{l}\text { Operations Control Trailer } \\
\text { (OCT) }\end{array}$ & $\begin{array}{l}\text { Design (FY94) } \\
\text { Procure (FY95) }\end{array}$ & \\
\hline 4200 & $\begin{array}{l}\text { Supervisory Control System } \\
\text { (SCS) / Supervisory Data } \\
\text { Acquisition System (SDAS) } \\
\text { Equipment }\end{array}$ & $\begin{array}{l}\text { Internal } \\
\text { components of the } \\
\text { Operations Control } \\
\text { Trailer (OCT) }\end{array}$ & $\begin{array}{l}\text { Replace in the Cold } \\
\text { Test Facility at the } \\
\text { time when the OCT is } \\
\text { transferred to EM- } 30 \text { so } \\
\text { that the LDUA System } \\
\text { cold unit can operate } \\
\text { and can be used for } \\
\text { training. } \\
\end{array}$ \\
\hline 4400 & Control Network & See System $\# 4200$ & $\begin{array}{l}\text { See System \#4200 } \\
\text { (FY96 funding) }\end{array}$ \\
\hline 4300 & At Tank Instrument Enclosure 9 & $\begin{array}{l}\text { Design (FY95-96) } \\
\text { Procure (FY96) }\end{array}$ & \\
\hline 5000 & \multicolumn{3}{|c|}{ UTILITIES } \\
\hline 5100 & Power Distribution Skid ${ }^{10}$ & Design (FY95-96) & $\begin{array}{l}\text { Procure (FY95-96) } \\
\text { (FY95 C.R. funding) }\end{array}$ \\
\hline 5100 & Power Cable and Handling ${ }^{11}$ & Design (FY95-96) & $\begin{array}{l}\text { Procure (FY95-96) } \\
\text { (FY96 funding) }\end{array}$ \\
\hline 5110 & Site Electrical Power & & As Required \\
\hline
\end{tabular}




\begin{tabular}{|c|c|c|c|}
\hline System \# & Equipment & EH-50 & EH-30 \\
\hline 5120 & Portable Generator & & As Required \\
\hline 5230 & LDUA Purge Air Supply & $\begin{array}{l}\text { Procure purge air } \\
\text { compressor (FY95) }\end{array}$ & \\
\hline 5300 & Water Systems & & $\begin{array}{l}\text { As required to support } \\
\text { Operations }\end{array}$ \\
\hline 5400 & Gas Systems & & $\begin{array}{l}\text { Nitrogen bottles as } \\
\text { required for } 4^{\prime \prime} \text { riser } \\
\text { deployed system purge }\end{array}$ \\
\hline 5510 & Tank Farm Communication System & & $\begin{array}{l}\text { Presumed to be hand- } \\
\text { held radios or other } \\
\text { SOP for Tank Farms }\end{array}$ \\
\hline 6000 & \multirow{2}{*}{\multicolumn{3}{|c|}{$\begin{array}{l}\text { END EFFECTORS } \\
\begin{array}{l}\text { Topographical Mapping System } \\
\text { (Independently Deployed) }\end{array}\end{array}$}} \\
\hline 6110 & & & \\
\hline 6210 & $\begin{array}{l}\text { Overview Video Camera System } \\
\text { (Independently Deployed) } \\
\end{array}$ & $\begin{array}{l}\text { Design (FY95) } \\
\text { Procure (FY95) }\end{array}$ & $\begin{array}{l}\text { Procure (FY95-96) } \\
\text { (2nd unit as needed) }\end{array}$ \\
\hline 6220 & $\begin{array}{l}\text { Overview Stereoscopic Video } \\
\text { Camera System'15 } \\
\text { (Independently Deployed) }\end{array}$ & $\begin{array}{l}\text { Design (FY95) } \\
\text { Procure (FY95) }\end{array}$ & $\begin{array}{l}\text { Procure (FY95-96) } \\
\text { (2nd unit as needed) }\end{array}$ \\
\hline 6230 & $\begin{array}{l}\text { High Resolution Stereoscopic } \\
\text { Video Camera System } \\
\text { (LDUA Deployed) }\end{array}$ & $\begin{array}{l}\text { Design (FY95) } \\
\text { Procure (FY95) }\end{array}$ & $\begin{array}{l}\text { Procure (FY96) } \\
\text { (FY95 C.R. funding) }\end{array}$ \\
\hline 6240 & $\begin{array}{l}\text { Still/Stereoscopic } \\
\text { Photographic System } \\
\text { (LDUA Deployed) } \\
\end{array}$ & Design (FY95) & $\begin{array}{l}\text { Procure (FY97 or later) } \\
\text { (FY97 or later funding) }\end{array}$ \\
\hline 6250 & $\begin{array}{l}\text { Optical Alignment Scope }{ }^{15} \\
\text { (LDUA Deployed) }\end{array}$ & Design (FY95) & $\begin{array}{l}\text { Procure (FY95-96) } \\
\text { (FY95 C.R. funding) }\end{array}$ \\
\hline 7000 & \multicolumn{3}{|c|}{ COLD IEST FACILITY (FMEF) } \\
\hline 7100 & Test Facility Modifications & $\begin{array}{l}\text { Provide facility } \\
\text { upgrades needed to } \\
\text { qualify LDUA } \\
\text { System } \\
\end{array}$ & \\
\hline 7200 & Test Equipment & $\begin{array}{l}\text { Provide test } \\
\text { equipment needed } \\
\text { to qualify LDUA } \\
\text { System }\end{array}$ & $\begin{array}{l}\text { Provide duplicates of } \\
\text { any test equipment as } \\
\text { needed to support } \\
\text { maintenance of the LDUA } \\
\text { System field unit }\end{array}$ \\
\hline
\end{tabular}




\begin{tabular}{|c|c|c|c|}
\hline \multicolumn{4}{|c|}{ EQUIPHENT SUPPLY RESPONSIBILITY FOR FIRST LDUA FIELD SYSTEY } \\
\hline System \# & Equipment & EM-50 & EM-30 \\
\hline 8000 & OTHER EQUIPMENT (MISC) & & 4. \\
\hline 8110 & $\begin{array}{l}\text { Plug Gages (for } 4 " \text { and } 12 " \\
\text { risers) }\end{array}$ & & $\begin{array}{l}\text { Design (FY94) } \\
\text { Procure (FY95) } \\
\text { (FY95 funding) }\end{array}$ \\
\hline 8200 & $\begin{array}{l}\text { LOUA Operations Overview Video } \\
\text { System (outside of tank) }\end{array}$ & & $\begin{array}{l}\text { Design (FY-TBD) } \\
\text { Procure (FY-TBD) } \\
\text { (recommended but not } \\
\text { required) } \\
\text { (FY } 96 \text { funding) }\end{array}$ \\
\hline 8300 & Maintenance Equipment ${ }^{15}$ & & Provide as required \\
\hline
\end{tabular}

Notes:

1. The first truck mounted LDUA unit received at Hanford will be the one that is actually deployed in the tank. Accordingly it will be transfermed to EM- 30 . The second truck mounted LDUA unit received at Hanford will be installed in the Cold Test Facility (CTF) and ownership will be transferred to EM-50.

2. EM-50 will supply Outrigger Pads suitable to accomnodate soil conditions at the Tank Farms.

3. EM-50 will not be supplying any end effector Tool Interface Plate (TIP) halves. They will be considered as part of each end effector and the supplier of the end effector will be responsible for obtaining them.

4. There are no plans for EM-50 to replace the radiation monitors for the CTF unit after qualification testing has been completed. The radiation monitors are not required to support further development activities of the LDUA System, nor are they required for cold operation. If EM-30 wishes the CTF unit to have radiation monitors after qualification testing, for example to allow for more realistic training, EM-30 is expected to provide them.

5. EM-50 is not planning on obtaining a Tank Riser Interface and Confinement (TRIC) enclosure for the CTF unit after qualification testing is complete.

Qualification testing will take place with the TRIC that is being designed and fabricated by EM-30 for their field unit. EM-50 does not require a TRIC to support further development activities of the LDUA System, not is it required for cold operation. If EM-30 requires the CTF unit to have a TRIC, for example to allow for more realistic training, EM-30 is expected to provide the TRIC enclosure.

6. A manual end effector exchange system will be required to support continued cold operations. A second unit must be available when the first unit leaves the CTF, EM-50 will provide a manual end effector exchange system for the EM-30 LDUA System and for the CTF system. 
7. EM-50 has no plans to replace the LDUA Operations Control Trailer (OCT) in the CTF following qualification testing. Desks, tables, and free-standing instrument racks will be used to house the equipment necessary for continued cold operations.

8. The Supervisory Control System (SCS)/Supervisory Data Acquisition System (SDAS) equipment consists mainly of computer workstations, software, and network interconnections. This equipment and software is necessary for continued cold operations of the LDUA CTF unit. EM-30 agrees to replace the SCS and SDAS equipment and software when the OCT. is turned over to EM-30 at the conclusion of qualification testing.

9. Following qualification testing of the LOUA System, at-tank electronics will be mounted in free-standing 19-inch instrument racks by EM-50. The environmental protection provided at the at-tank instrument enclosure will not be required to support cold operations.

10. EM-50 has no plans to replace the power distribution skid following qualification testing. Simple modifications to the CTF power systems by EM-50 will be adequate to support continued cold operations.

11. EM-50 will provide the necessary power cabling in the CTF to support continued cold operations.

12. The scope of supply of end effectors is understood to include the necessary support electronics and software, and the interface to the SDAS. The end effector half of the Tool Interface Plate (TIP) is also considered to be the responsibility of the end effector supplier. EM-30 will be responsible for supplying suitable transport containers for LDUA end effectors.

13. The Topographical Mapping System (TMS) supplied by EM-50 to EM-30 will not have a Tank Riser Interface Module (TRIM) necessary for in-tank deployment. The TRIM will be supplied by EM-30.

14. It is expected that EM-50 development of the $62 x x$ series of end effectors will continue following qualification testing to incorporate lessons learned from that testing and from initial hot operations. Accordingly, new versions will be obtained by EM-50 as part of the continuing cold operations.

15. The LDUA Vertical Positioning Mast (VPM) spreader bar for hoisting the VPM off of the truck and onto the ground will be provided by EM-50. In addition, the LDUA vehicle lifting fixture for hoisting the entire LDUA System will be provided by EM-50. All other maintenance equipment shall be supplied by EM-30. 
Memorandum of Understanding EM-30 Responsibility Matrix

\begin{tabular}{|c|c|c|c|}
\hline Systen Ko. & Lead Engineer & Org. Code & Manager \\
\hline 2000 & G. R. Kiebel/T. J. Semuel & 84800 & D. S. Dutt \\
\hline 2100 & G. R. Kiebel/T. J. Samuel & 84800 & D. S. Dutt \\
\hline 2200 & G. R. Kiebel/T, d. Semuel & 84800 & D. S. Outt \\
\hline 2300 & G. R. Kiebel/T. J. Sanuel & 84800 & D. S. Dutt \\
\hline 2400 & G. R. Kiebel/T. J. Semuel & 84800 & D. S. Dutt \\
\hline 3000 & $N / A$ & & \\
\hline 3520 & $\mathbf{L} / \mathbf{a}$ & & \\
\hline 3660 & U. R. Jacuish & 74420 & R. K. Brown \\
\hline 3700 & U. R. Jacuish & 74420 & R. K. Brown \\
\hline 4000 & N/A & & \\
\hline 4100 & $\mathbf{N} / \mathbf{A}$ & & \\
\hline 4200 & J. E. Ellis/R. Truit & 84800 & D. S. Dutt \\
\hline 4300 & $\mathbf{N} / \mathbf{A}$ & & \\
\hline 4400 & J.E. Ellis & 84800 & D. S. Dutt \\
\hline 5000 & D. A. Clark & 84800 & D. S. Dutt \\
\hline 5100 & D. A. Clark & 84800 & D. S. Dutt \\
\hline 5110 & B. R. Johns & 75230 & D. U. Henilton \\
\hline 5120 & B. R. Johns & 75230 & D. U. Hamilton \\
\hline 5230 & $\mathrm{~N} / \mathrm{A}$ & & \\
\hline 5300 & U. R. Jacuish & 74420 & R. K. Broin \\
\hline 5400 & $N / A$ & & \\
\hline 5510 & R. B. Conrad & 75240 & R. E. Baver \\
\hline 6110 & A. F. Pardini & 84800 & D. S. Dute \\
\hline 6210 & D. A. Langlois & 75140 & D. A. Lenglois \\
\hline 62230 & D. A. Langlois & 75140 & D. A. Langlois \\
\hline 6230 & R. B. Conrad & 75240 & R. E. Bauer \\
\hline 6240 & $N / A$ & & \\
\hline 6250 & R. B. Conred & 75240 & R. E. Baver \\
\hline 7100 & N/A & & \\
\hline 7200 & R. B. Conrad & 75240 & R. E. Bauer \\
\hline 8110 & R. B. Conrad & 75240 & R. E. Bayer \\
\hline 8200 & A. F. Pardini & $8 \wedge 800$ & D. S. Dutt \\
\hline 8300 & R. B. Conred & 75240 & R. E. Baver \\
\hline
\end{tabular}


WHC-SD-WM-ETP-176 Rev. 0

This page intentionally left blank. 
WHC-SD-WM-ETP-176 Rev. 0

APPENDIX 0

ACCEPTANCE FOR BENEFICIAL USE

D-1 
WHC-SD-WM-ETP-176 Rev. 0

This page intentionally left blank. 


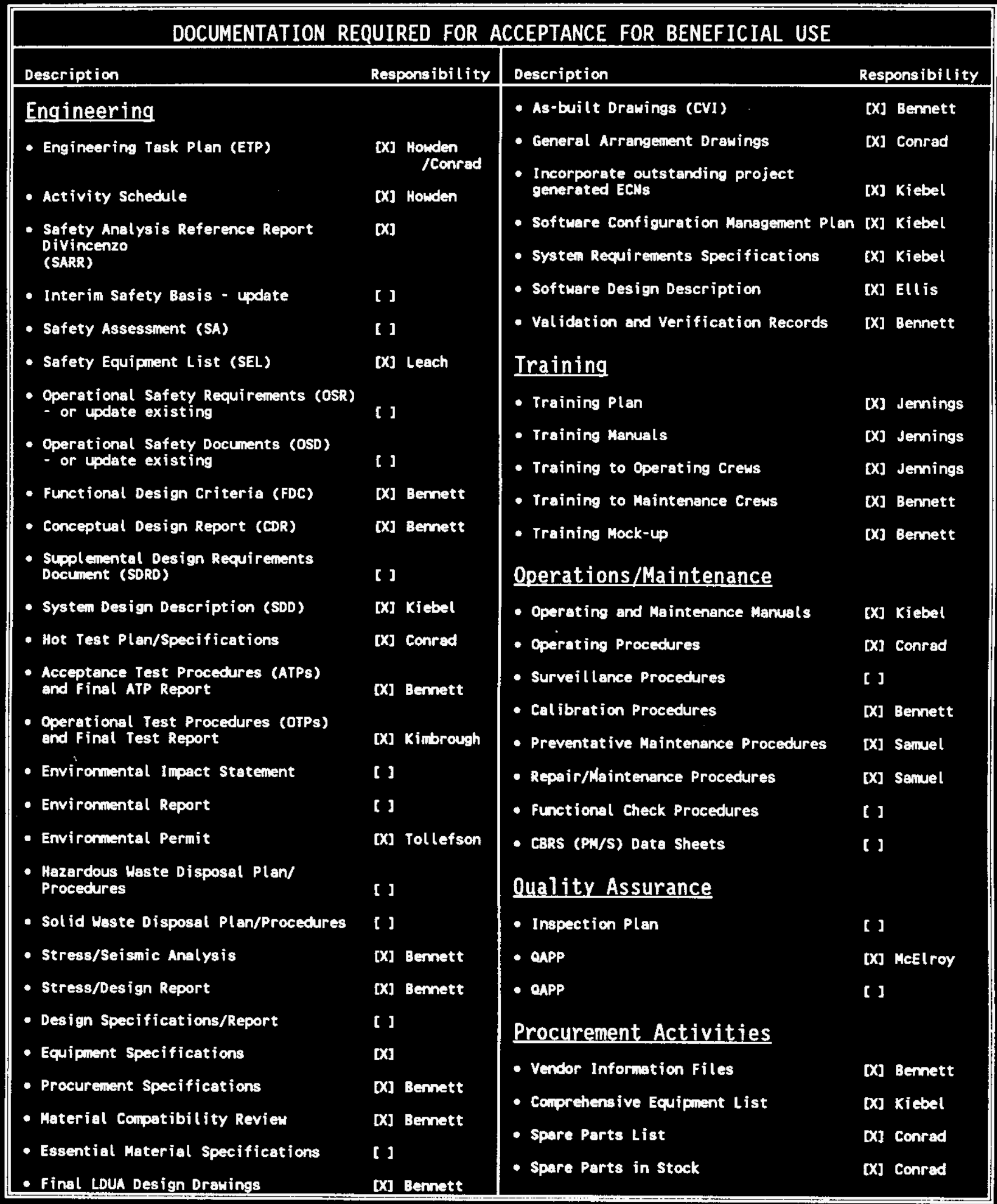




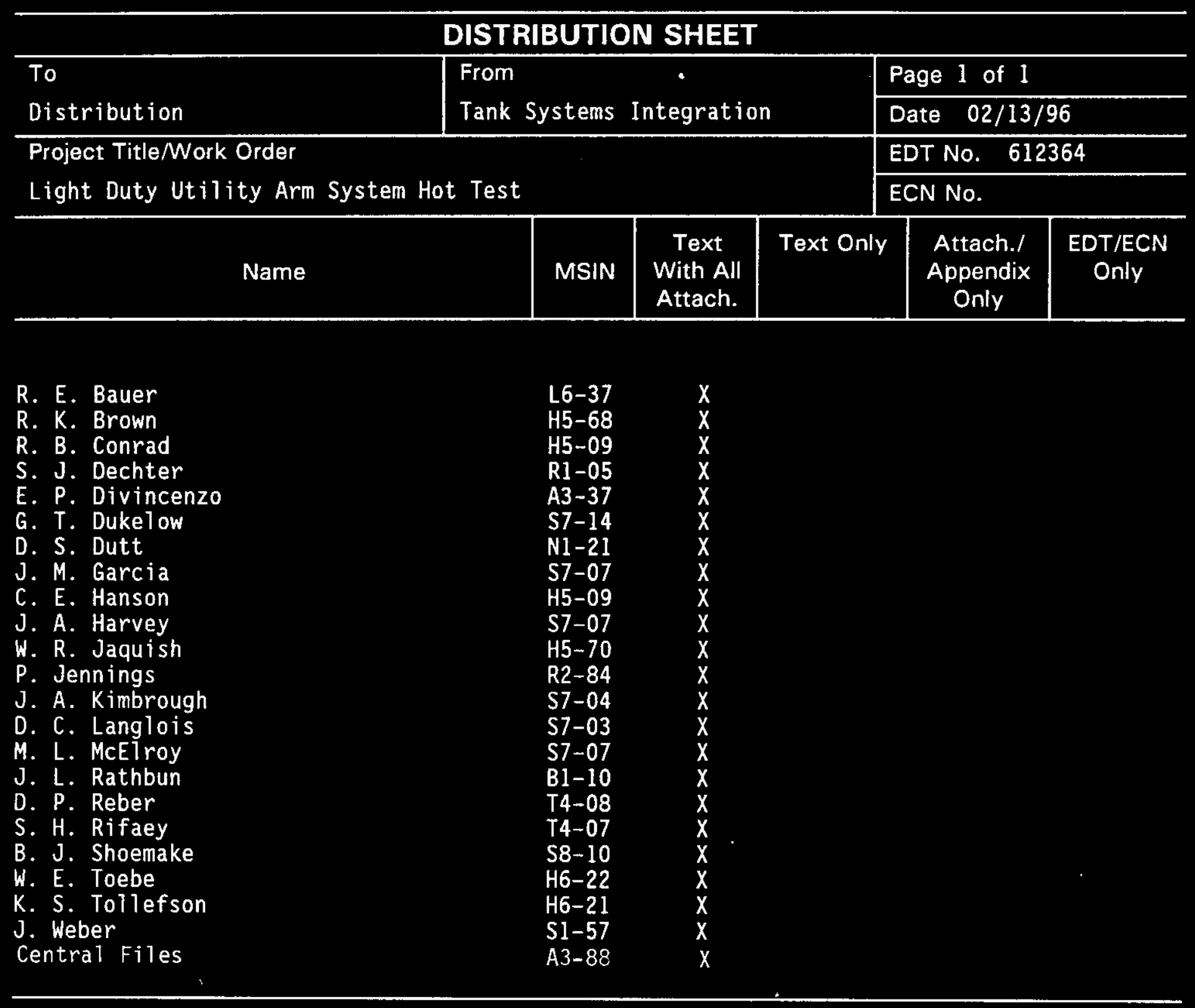

